\title{
In vitro Anti Leukemia Cancer Activity of Some Novel Pyrazole Derivatives and Pyrazoles Containing Thiazole Moiety
}

\author{
Amal Mahmoud Youssef Moustafa \\ Chemistry Department, Faculty of Science, Port Said University, Port Said, Egypt \\ Email address: \\ moustafaamm@yahoo.com \\ To cite this article: \\ Amal Mahmoud Youssef Moustafa. In vitro Anti Leukemia Cancer Activity of Some Novel Pyrazole Derivatives and Pyrazoles Containing \\ Thiazole Moiety. American Journal of Heterocyclic Chemistry. Vol. 5, No. 3, 2019, pp. 55-70. doi: 10.11648/j.ajhc.20190503.12
}

Received: June 30, 2019; Accepted: August 1, 2019; Published: August 14, 2019

\begin{abstract}
The design and syntheses of several novel pyrazole derivatives (2, 5, 6 and 7) and pyrazole derivatives (3 and 4) containing thiazole moiety via by ethyl $\beta$-( $p$-chlorophenyl)- $\alpha$-cyanoacrylate $(1)$ and thiosemicarbazide as starting materials. Pyrazole derivatives ( 3 and 4 ) containing thiazole moiety were synthesized via cyclization of pyrazole derivative (2) with bromomethyl arylketones, to give compound 3, followed by acetylation. N- (3- methoxy-2-hydroxybenzal) -3- ( $p$ chlorophenyl)-4- cyano-5-oxopyrazol-1-thiocarboxamide (6) was synthesized via reaction of compound 2 with 3-methoxy-2hydroxybenzaldehyde. Structures of all compounds were confirmed by elemental analysis, FT-IR, ${ }^{1} \mathrm{H}-\mathrm{NMR}$, ${ }^{13} \mathrm{C}-\mathrm{NMR}$ and mass spectrometry. The cytotoxic activity of all the synthetic compounds were evaluated against Leukemia HL-60 compared with Doxorubicicn. The cytotoxic activity was checked in vitro for the recently prepared compounds by using the MTT assay. Compounds 4, 6 and 9 were the most active against Leukemia HL-60. The $\mathrm{IC}_{50}$ values of them were less than $5 \mu \mathrm{M}$ in the range of 1.35-4.78 $\mu \mathrm{M}$. In addition, compounds 3 and 5 showed less antiproliferative activity against Leukemia HL-60 cells with $\mathrm{IC}_{50}$ values in the range 5.39-8.82 $\mu \mathrm{M}$. Compound 6 was the most potent cytotoxic activity. The studies biological activity includes cell cycle analysis, apoptosis detection assay and Topoisomerase II inhibition activity assay explained that compound 6 is a strong Topo II inhibitor.
\end{abstract}

Keywords: Pyrazole, Thiazole, Antiproliferative, Cell Cycle Analysis, Annexin-V, Topoisomerase II

\section{Introduction}

Nitrogen and sulphur heterocyclic compounds are extensively dispersed in natural world and are vital to life [1]. Among the wide range of heterocycles containing thiazole and pyrazolinone moeites investigated currently, heterocycles containing thiazole derivatives which have diverse biological activities [2-11]. Thiazole derivatives are remarkable in the biological activity of natural products and many potent biologically active molecules such as vitamine B1, sulphathiazole, abafungin and tiazofurin, epothilones, nizatidine and ritonavir [12-23].

Thiazoles are a familiar group of heterocyclic compounds possessing a wide variety of biological activities such as antimicrobial [24], antioxidant [25], antitubercular [26], anticonvulsant [27], anticancer [28-34], antiallergic [12] and anti-inflammatory $[35,36]$ agents.
Thiazole derivatives are recognized for their antihypertensive, antischizophrenia, hypnotics, anti-HIV, analgesic, fibrinogen receptor antagonist, bacterial DNA gyrase B inhibitor [12-23].

The presence of the pyrazole nucleus in different structures leads to diversified applications in different areas such as technology, medicine and agriculture. In particular, they are described as inhibitors of protein glycation, antimicrobial [37, 38], antidepressant [39, 40], anticonvulsant [41], antifungal [42, 43], and antitubercular [44, 45], anticonvulsant [46], DPPH radical Scavenging, anti-diabetic [47], antiamebic [48], as well as antiviral agents [49]. Pyrazole analogoues can selectively inhibit (cyclooxygenase enzyme) COX-2 [50] they are also expressing antiinflammatory [51], analgesic [52], antihypertensive, antipyretic, sedatives, and antidiabetic activities [53-55].

Further, derivatives of pyrazoles have shown significant 
pharmacological activities, such as antitumor [56-59] antileukemic [60-62] and antiproliferative [63, 64] agents. In addition to their ability to apply remarkable anticancer effects throughout the inhibition of different types of enzymes which play significant roles in cell division [65-67]. As an expansion of our preceding work [68-70], this research reported the syntheses of some novel heterocyclic compounds including thiazole moiety attached to pyrazolinone ring at N-1 using ethyl $\beta$ - (p-chlorophenyl) $-\alpha$ cyanoacrylate (1) as a key starting material.

These arrangements were suggested as a trial to increase the activity against leukemia cancer cells. Hoping to find out a new guide combination structure which that would have a considerable anti- leukemia potential with small concentrations.
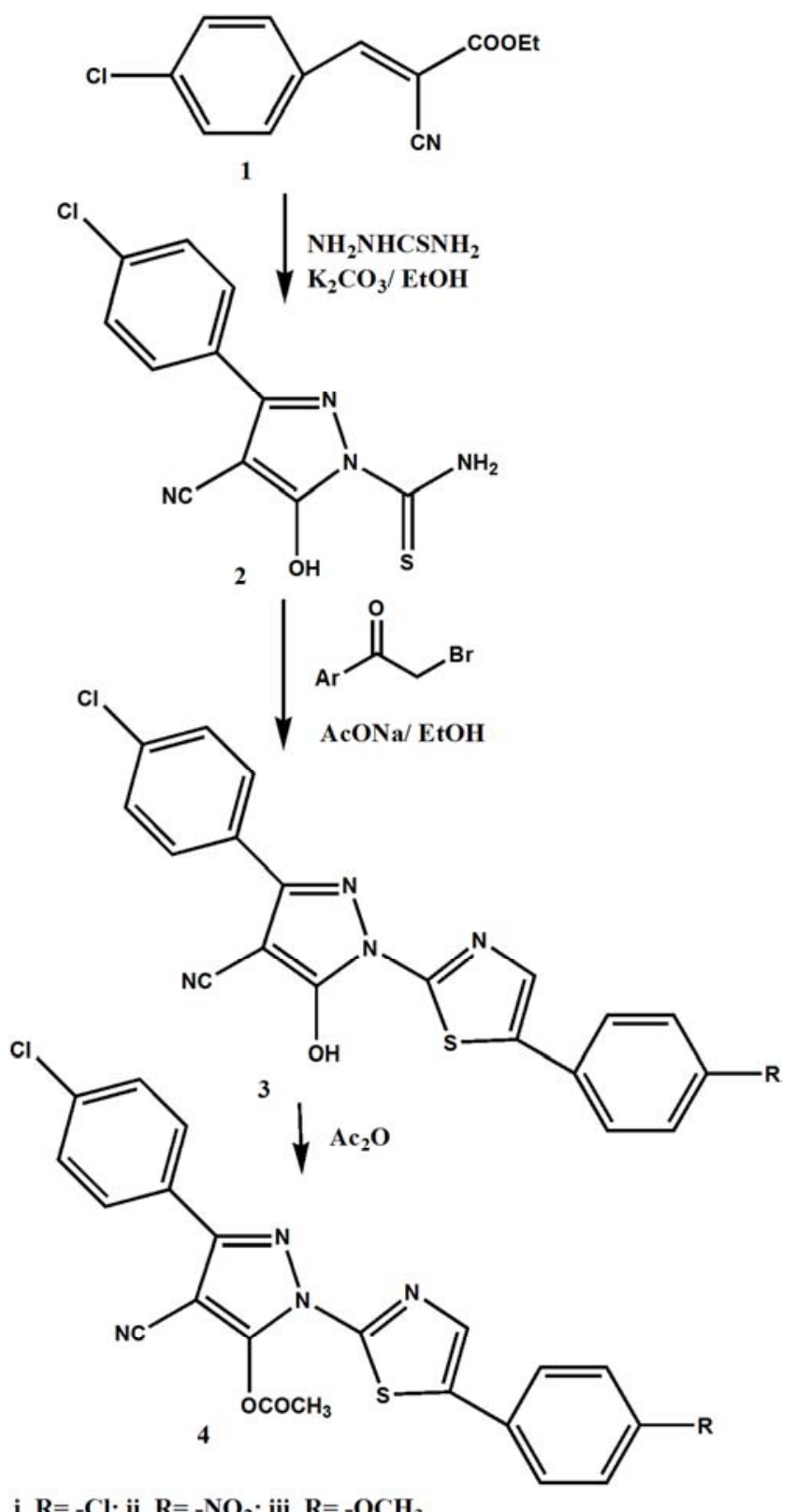

i, $\mathrm{R}=-\mathrm{Cl}$; ii, $\mathrm{R}=-\mathrm{NO}_{2} ;$ iii, $\mathrm{R}=-\mathrm{OCH}_{3}$

Figure 1. Syntheses of pyrazole derivatives (3 and 4) containing thiazole moiety.

\section{Results and Discussion}

\subsection{Chemistry}

The structural diversity and biological importance of pyrazole and thiazole derivatives have made them attractive targets for synthesis. The syntheses of the new heterocyclic compounds contain thiazole and pyrazole moieties (3 and 4) are described in "Figure 1".

The initial compound ethyl $\beta$ - ( $p$-chlorophenyl) - $\alpha$ - cyanoacrylate (1) was reacted with thiosemicarbazide and ethanol in the existence of anhydrous potassium carbonate to make the 3- ( $p$-chlorophenyl)-4-cyano-5-hydroxypyrazol-1thiocarboxamide (2).

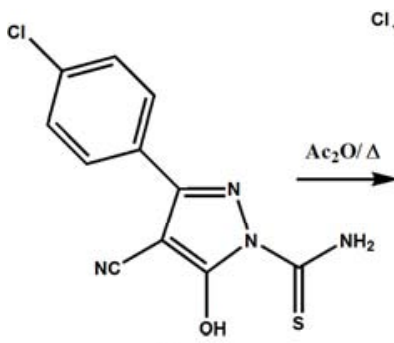

2<smiles>COc1cccc(/C=N/C(=S)n2nc(-c3ccc(Cl)cc3)c(C#N)c2O)c1O</smiles>

6

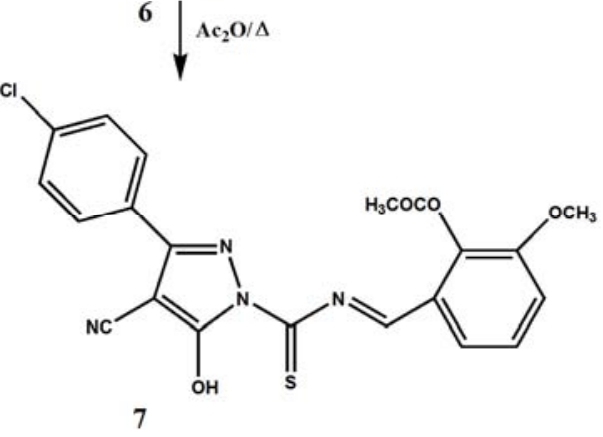

Figure 2. Syntheses of some pyrazol-1-thiocarboxamide derivatives (5-7).

Cyclocondensation of pyrazol- 1- thiocarboxamide derivative (2) with various aryl bromomethyl ketones (such as $p$ - chlorophenacyl bromide, $p$ - nitrophenacyl bromide and $p$-meth-oxyphenacylbromide) and ethanol in the existence of fused sodium acetate gave 5- hydroxyl-4-cyano-3(chlorophenyl) -1- (5- arylthiazol -2-yl) - pyrazoles (3a-c).

1-substituted-pyrazole derivatives (3) was heated with acetic anhydride under reflux to form 5- acetoxy-4-cyano-3( $p$-chlorophenyl-1-(5-aryl-thiazole-2-yl)-pyrazoles (4a-c).

The synthetic strategies adopted to obtain N-substituted 5- 
oxopyrazole-1-thiocarboxamide derivatives, is demonstrated in "Figure 1".

The conversion of compound 2 into the N- acetyl 5acetoxy-4-cyano-( $p$-chlorophenyl)-pyrazol-1-

thiocarboxamide (5) was achieved by heating the 5-hydroxy4-cyano-3-( $p$-chlorophenyl)-pyrazol-1-thiocarboxamide with acetic anhydride under reflux.

Condensation of pyrazole derivative (2) with 3-methoxy-2hydroxybenzaldehyde in acetic acid yielded the target $\mathrm{N}-(m-$ methoxy-o-hydroxybenzal) -5-hydroxy-4-cyano-3-( $p$ chlorophenyl)-pyrazol-1-thiocarboxamide (6). Acetylation of the latter compound with acetic anhydride under boiling resulted in the corresponding $\mathrm{N}$ - $(m$-methoxy- $o$-acetoxybenzal)-5-hydroxy-4-cyano-3-( $p$-chlorophenyl)-pyrazole-1thiocarboxamide 7, " Figure 2".

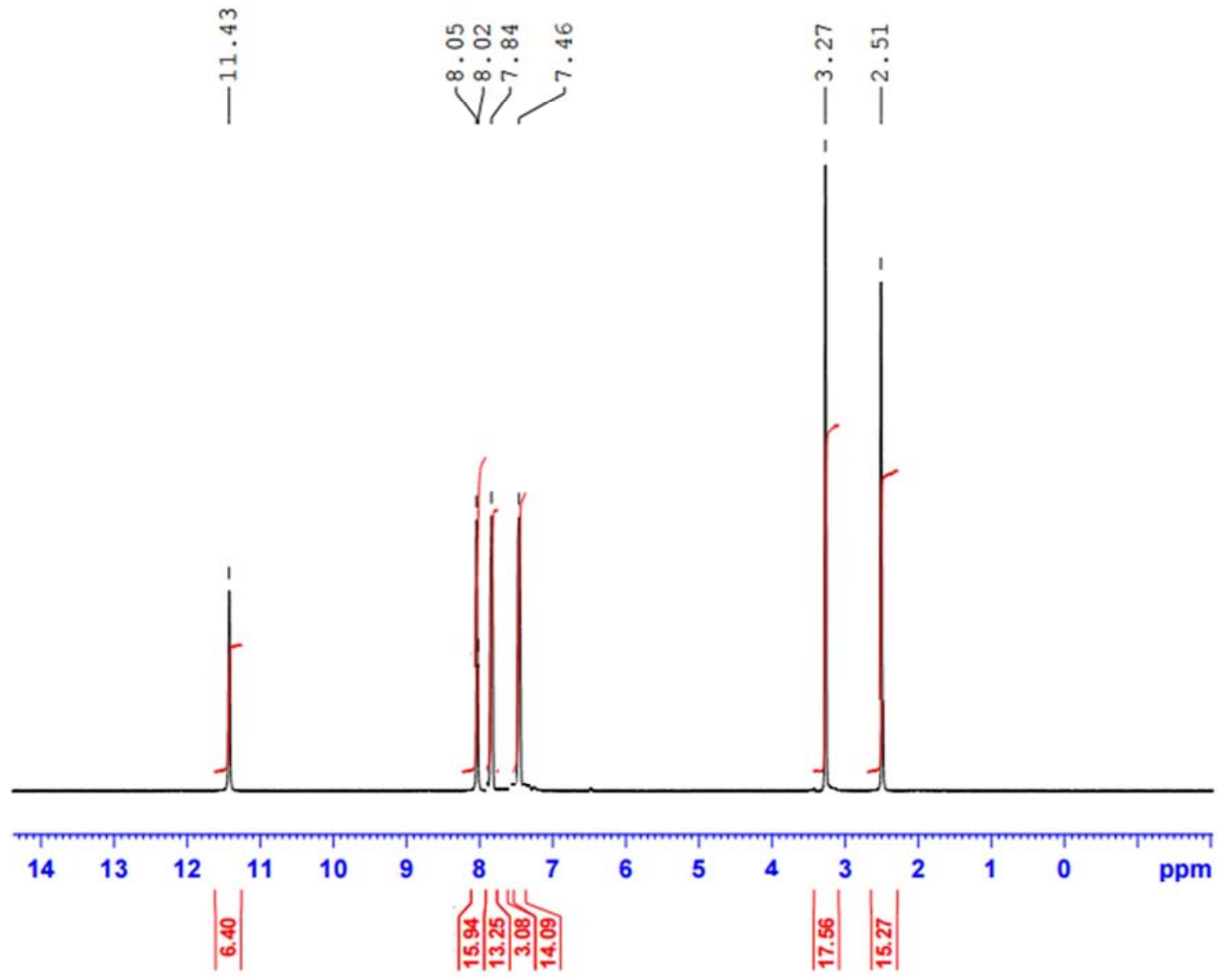

Figure 3. ${ }^{1} H-N M R$ spectrum of compound 2 .

IR spectrum of compound 5 displayed the lack of the absorption bands of $\mathrm{NH}_{2}$, but the absorption bands observed at $3216 \mathrm{~cm}^{-1}$ attributed to $\mathrm{NH}$ group. Bands at 1606, 1583 were attributed to $\mathrm{C}=\mathrm{C}$. Bands at 1715,1695 were due to $\mathrm{C}=\mathrm{O}$ group. Absorption band at $1625 \mathrm{~cm}^{-1}$ was due to $\mathrm{C}=\mathrm{N}$ group, and band at $2252 \mathrm{~cm}^{-1}$ was due to $\mathrm{CN}$ group and bands $1098,1071 \mathrm{~cm}^{-1}$ revealed the presence of $\mathrm{C}-\mathrm{O}$ group.

${ }^{1} \mathrm{H}-\mathrm{NMR}$ spectrum of compound 5 "Figure 4" gave cut evidence singlet signal at $\delta 11.73 \mathrm{ppm}$ attributed to the proton of NH group and two singlet signals at $\delta 2.21,2.05$

\subsection{NMR Spectra Investigation of Substituted Pyrazoles and Pyrazole Containing Thiazole Moiety}

\subsubsection{Substituted Pyrazoles (2 and 5)}

FT-IR spectrum of compound 2 showed the predictable absorption bands at $\delta 3437$ corresponding to hydroxyl group, and $\delta 3328, \delta 3181$ due to $\mathrm{NH}_{2}$ group. Stretching vibration bands at $\delta 2235,1632,1605,1585 \mathrm{~cm}^{-1}$ revealed the presence of $\mathrm{CN}, \mathrm{C}=\mathrm{C}$ and $\mathrm{C}=\mathrm{N}$, respectively.

In the ${ }^{1} \mathrm{H}-\mathrm{NMR}$ spectrum of compound 2 "Figure $3 "$ displayed two singlet signals at $\delta 11.43$ and $7.46 \mathrm{ppm}$ assignable to the protons of $\mathrm{OH}$ and $\mathrm{NH}_{2}$ groups respectively, beside two doublet signals at $\delta 7.84 \& 8.02 \mathrm{ppm}$ revealed to adjacent two protons of aromatic ring. ppm due to two acetyl groups. The outstanding proton signals are appearing in the predictable area of basic nucleus. In ${ }^{13} \mathrm{C}$ NMR spectrum of compound 5 "Figure 5 " showed signal at $\delta$ 193.55 was due to $\mathrm{C}=\mathrm{S}$ group. Two signals appeared in $\delta$ 169.90 and 167.94 were assignable to $\mathrm{C}=\mathrm{O}$ group, in addition to two signals showed at 23 and $22.28 \mathrm{ppm}$ characteristic of two methyl groups. Also, displayed signals in the range $\delta$ 154.25-115.83 ppm corresponding to carbons of aromatic, pyrazole and cyano groups. 


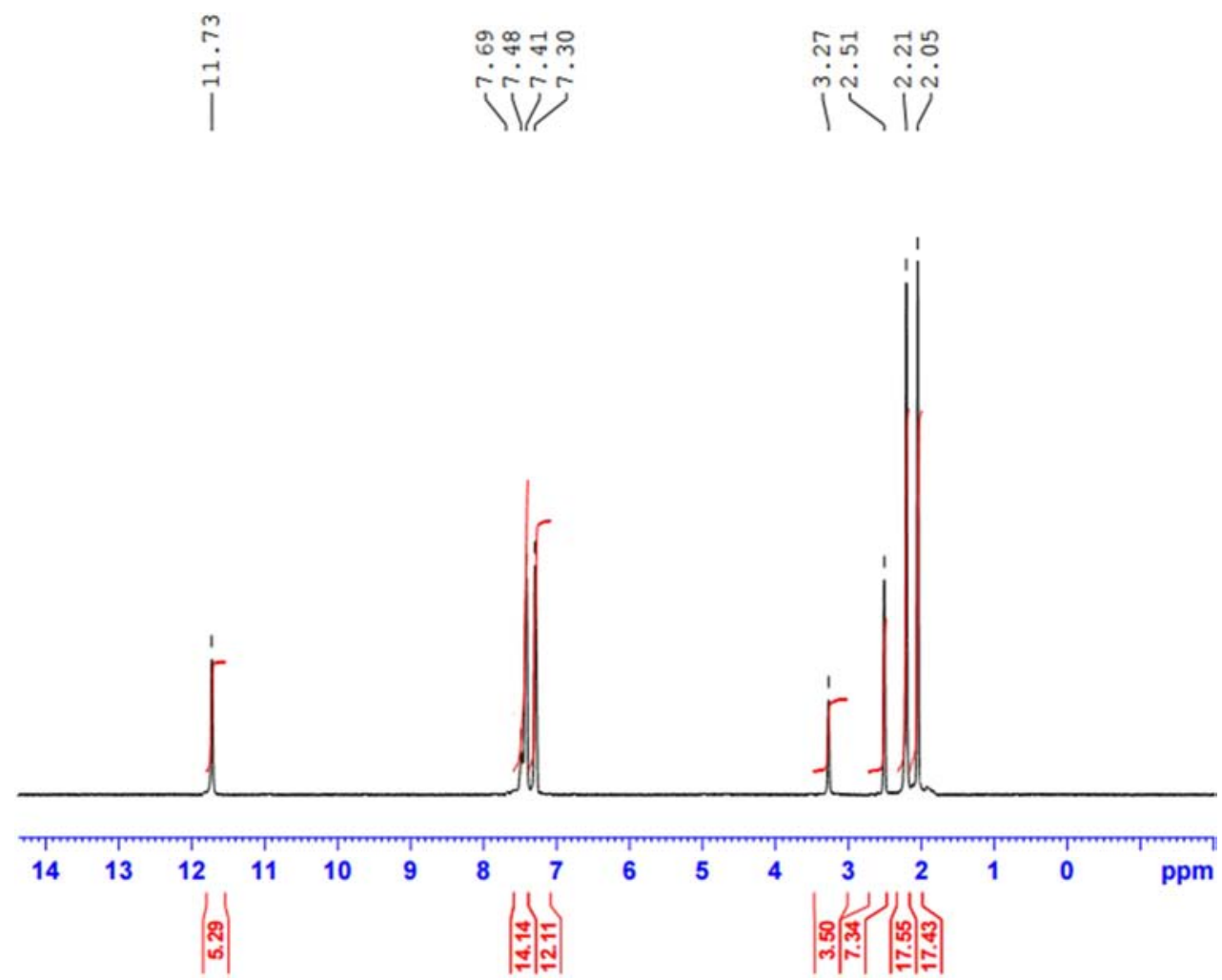

Figure 4. ${ }^{1} H$-NMR spectrum of compound 5 .
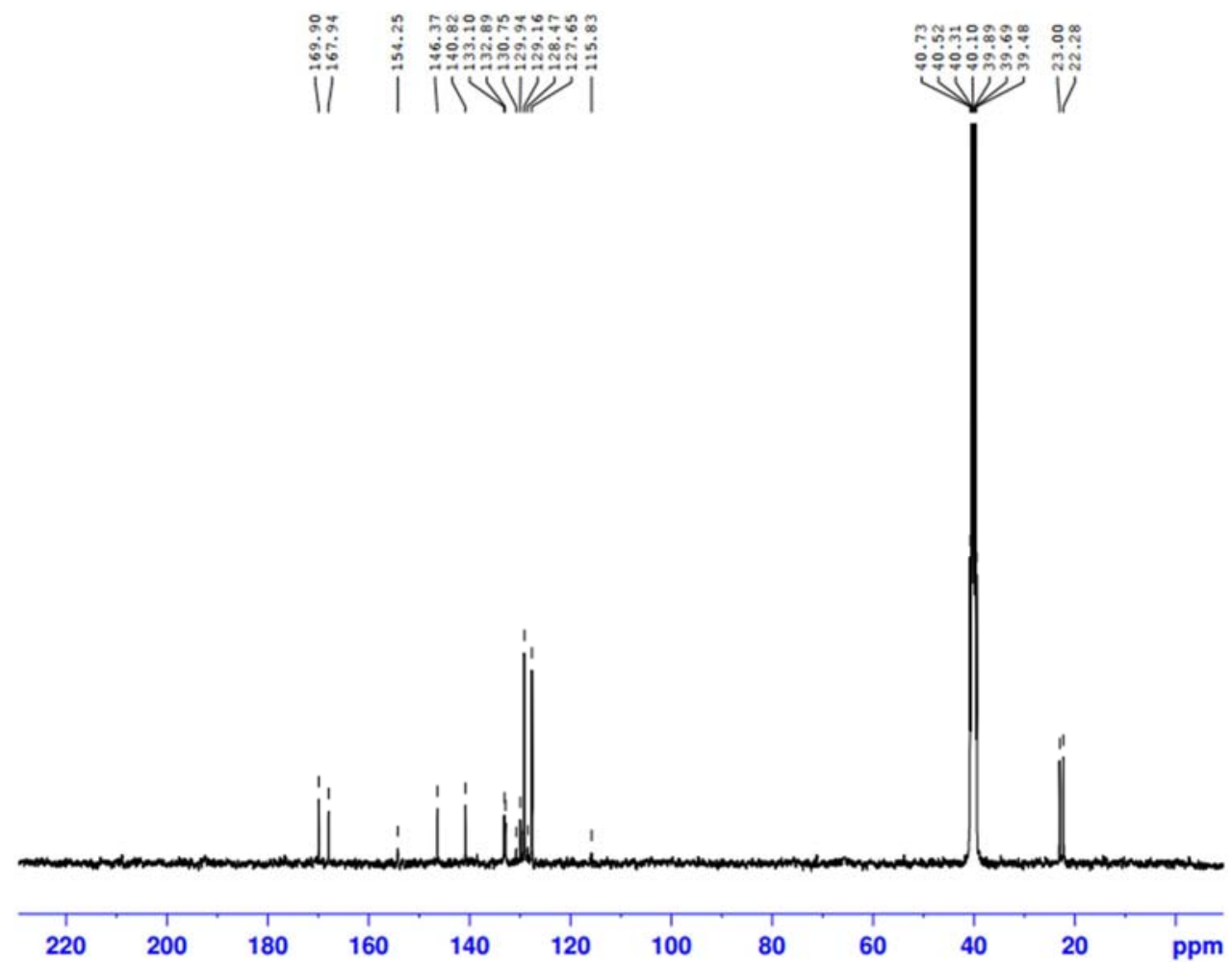

Figure $5 .{ }^{13}$ C-NMR spectrum of compound 5 .

\subsubsection{1-(Thiazolyl)-Pyrazole Derivatives (3 and 4)}

The ${ }^{1} \mathrm{H}-\mathrm{NMR}$ spectra of compound $3 \mathrm{a}$ "Figure 6" displayed a sharp singlet signal at $\delta 12.20 \mathrm{ppm}$ due to the proton of $\mathrm{OH}$ group for the pyrazole ring at C-5. Protons of the aromatic and thiazole ring of compound $3 \mathrm{a}$ were showed at $\delta$ 7.39-8.05 ppm.

${ }^{13} \mathrm{C}-\mathrm{NMR}$ spectrum of compound $3 \mathrm{a}$ "Figure 7" showed carbons of aromatic and thiazole ring noticed within the chemical shift regions and demonstrated integral values. 


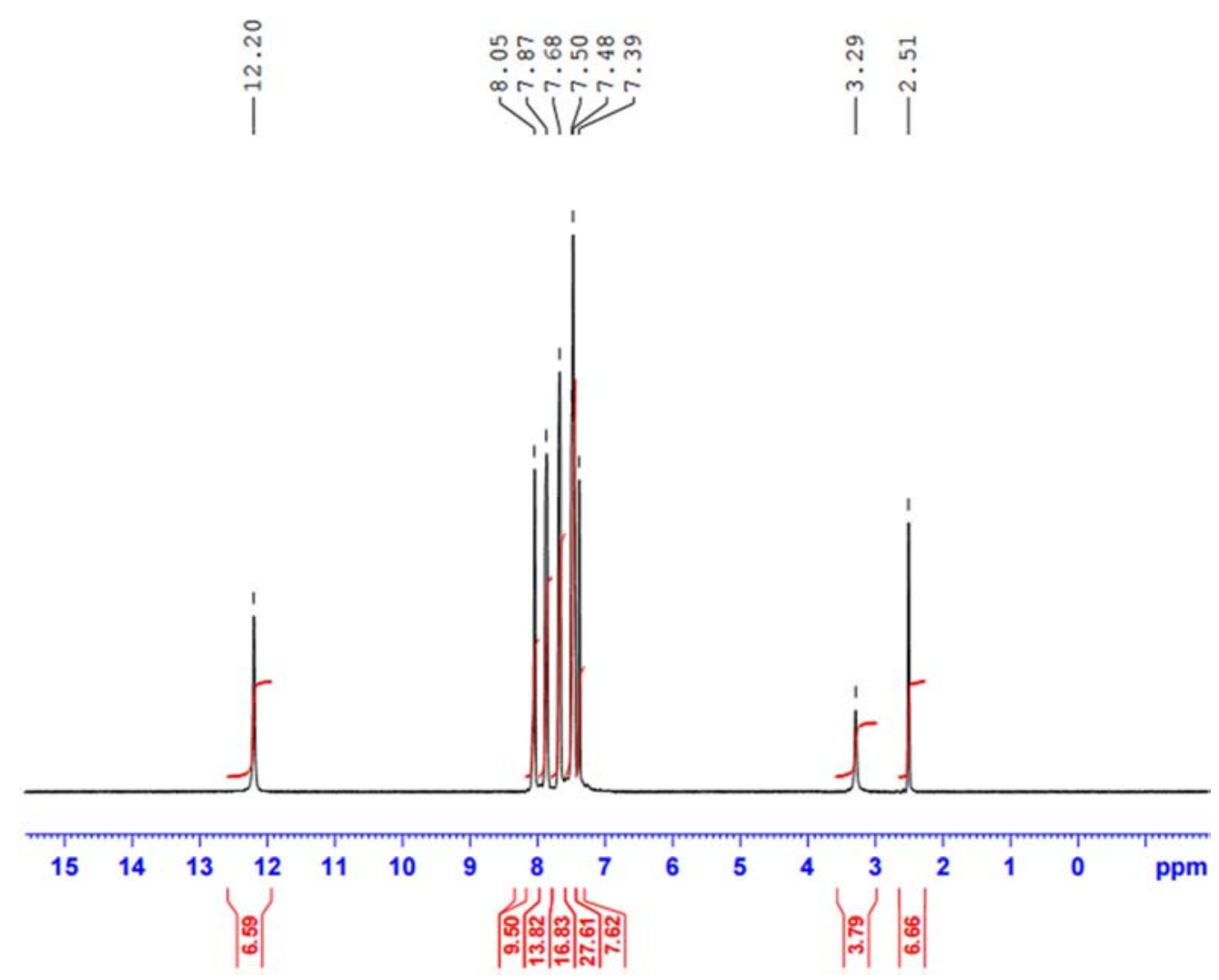

Figure 6. ${ }^{1} H$-NMR spectrum of compound $3 a$.
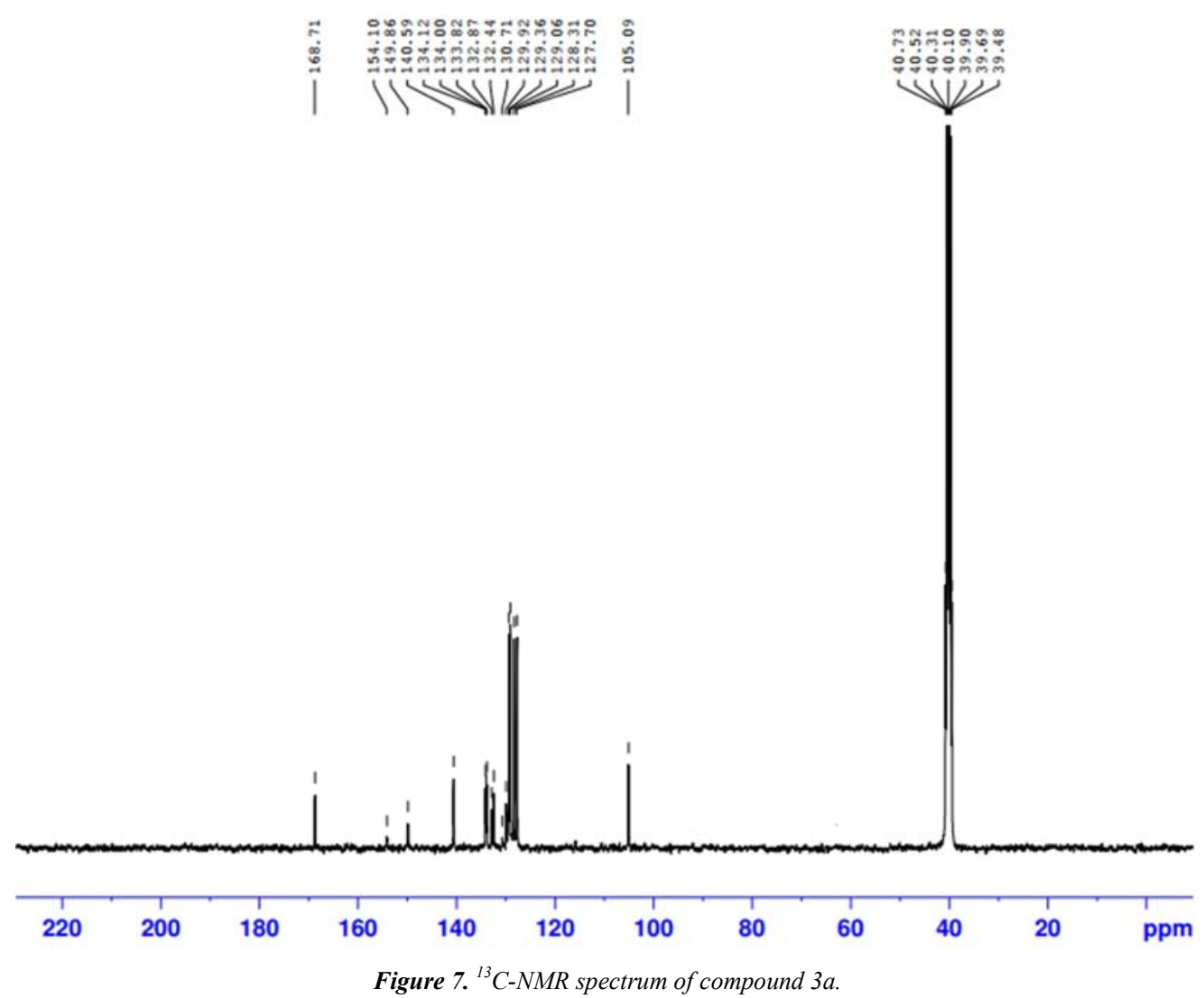

The ${ }^{1} \mathrm{H}-\mathrm{NMR}$ spectra of compound $3 \mathrm{~b}$ "Figure 8 " showed a sharp singlet signal at $\delta 11.43$ ppm characteristic to the proton of $\mathrm{OH}$ group for the pyrazole ring at C-5. Protons of the aromatic and thiazole ring of compound 3b were assignable at $\delta 7.45$ $8.33 \mathrm{ppm}$. 

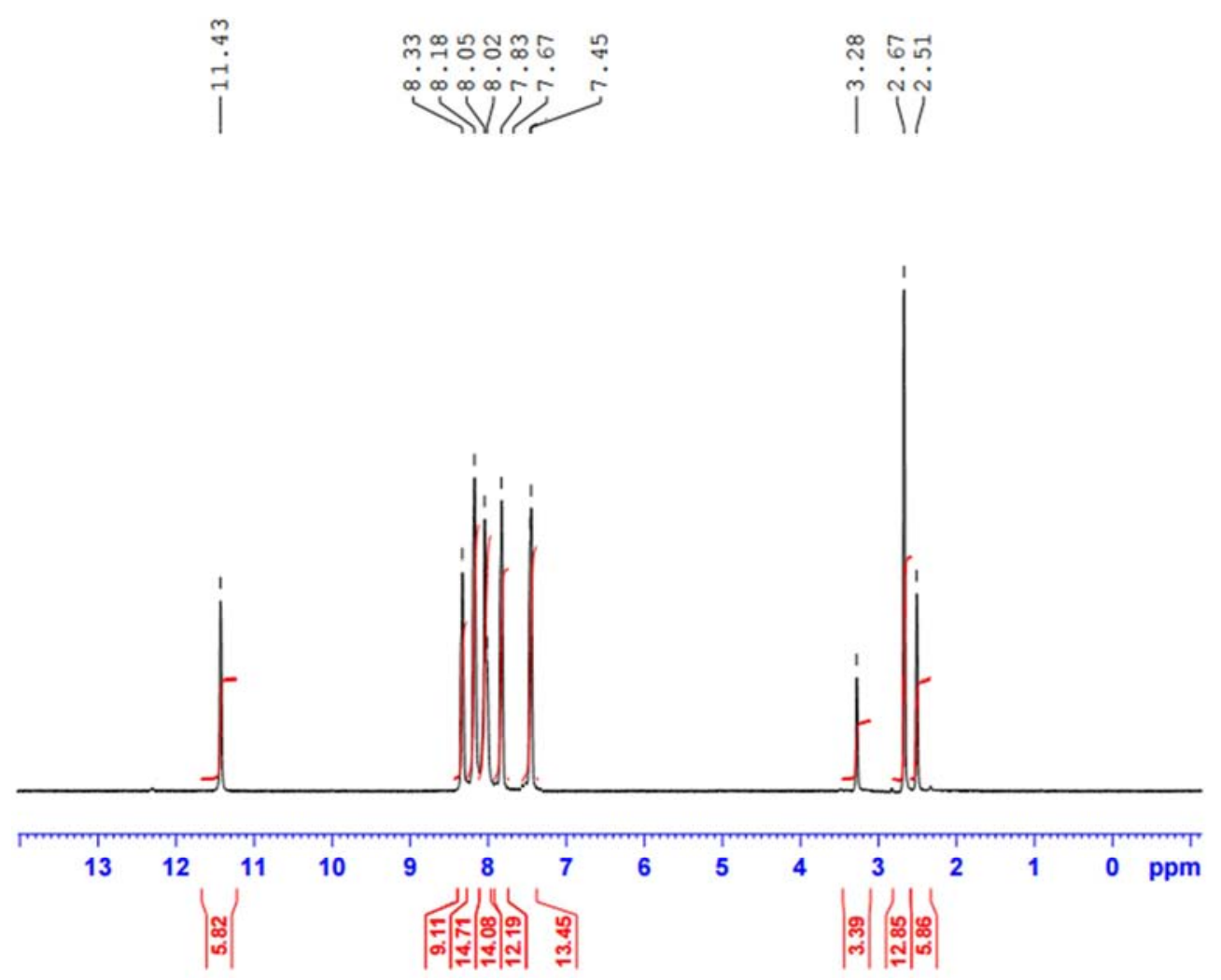

Figure 8. ${ }^{1} H$-NMR spectrum of compound $3 b$.

The ${ }^{1} \mathrm{H}-\mathrm{NMR}$ spectra of compound 3c "Figure 9" displayed a sharp singlet signal at $12.16 \mathrm{ppm}$ due to the proton of $\mathrm{OH}$ group for the pyrazole rings at $\mathrm{C}-5$. Protons of the aromatic and thiazole ring of compound $3 \mathrm{c}$ were due to $\delta$

\subsection{7-8.04 ppm.}

${ }^{1} \mathrm{H}-\mathrm{NMR}$ spectrum of compound $3 \mathrm{c}$ explained a sharp singlet signal at $\delta 3.79 \mathrm{ppm}$ due to the protons of methoxy group $\left(\mathrm{OCH}_{3}\right)$.

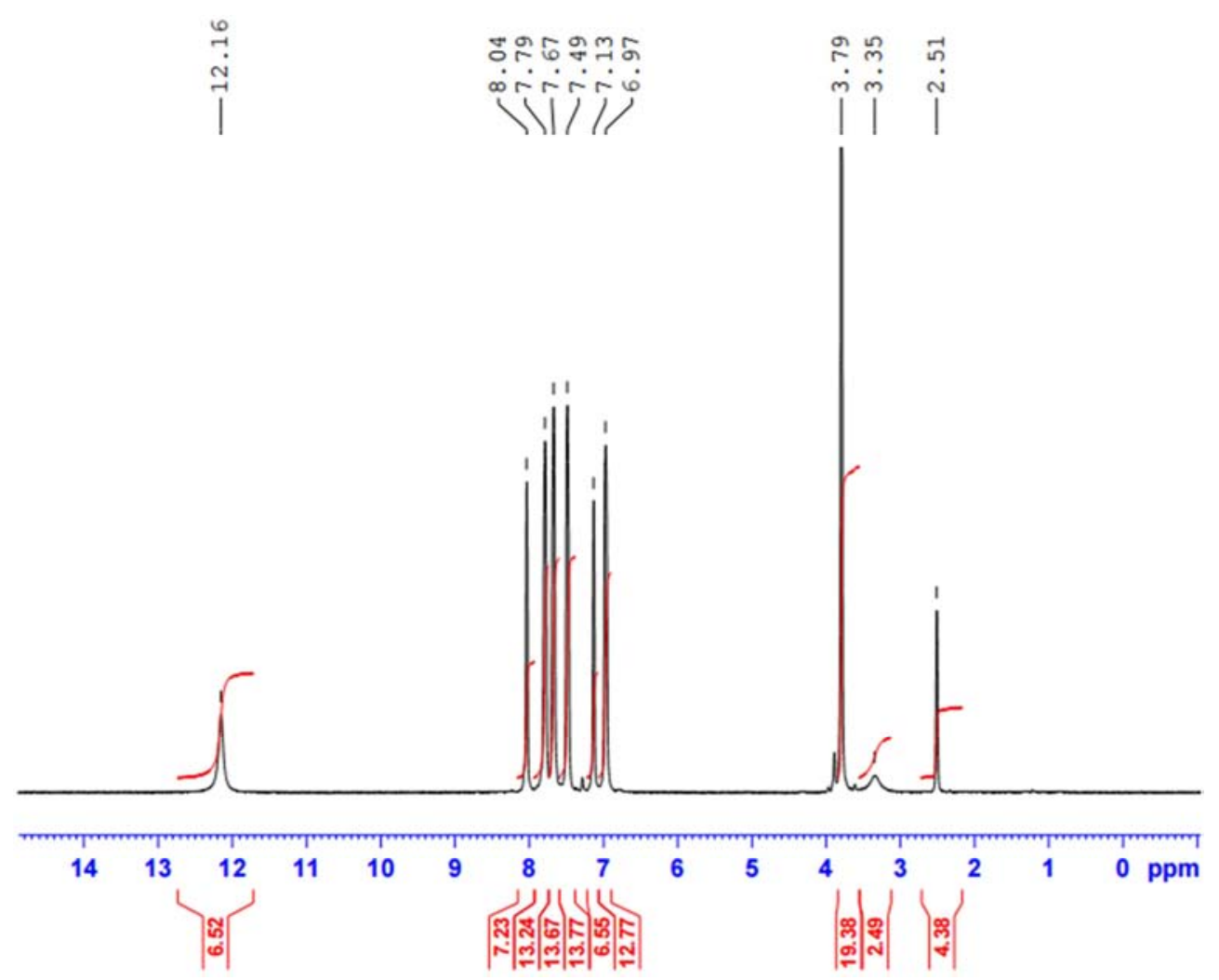

Figure 9. ${ }^{I} H$-NMR spectrum of compound $3 c$. 
In the ${ }^{1} \mathrm{H}-\mathrm{NMR}$ spectra of compounds $4 \mathrm{a}-\mathrm{c}$ showed the absence of singlet signals in the region at $\delta$ 12.33-11.91 ppm represented to the protons of hydroxyl groups $(\mathrm{OH})$, while the ${ }^{1} \mathrm{H}-\mathrm{NMR}$ spectra of compounds $4 \mathrm{a}-\mathrm{c}$ showed the new singlet signals in the region at $\delta 2.32-2.50 \mathrm{ppm}$ assignment to acetyl groups $\left(\mathrm{CH}_{3} \mathrm{CO}\right)$. The ${ }^{1} \mathrm{H}-\mathrm{NMR}$ spectrum of

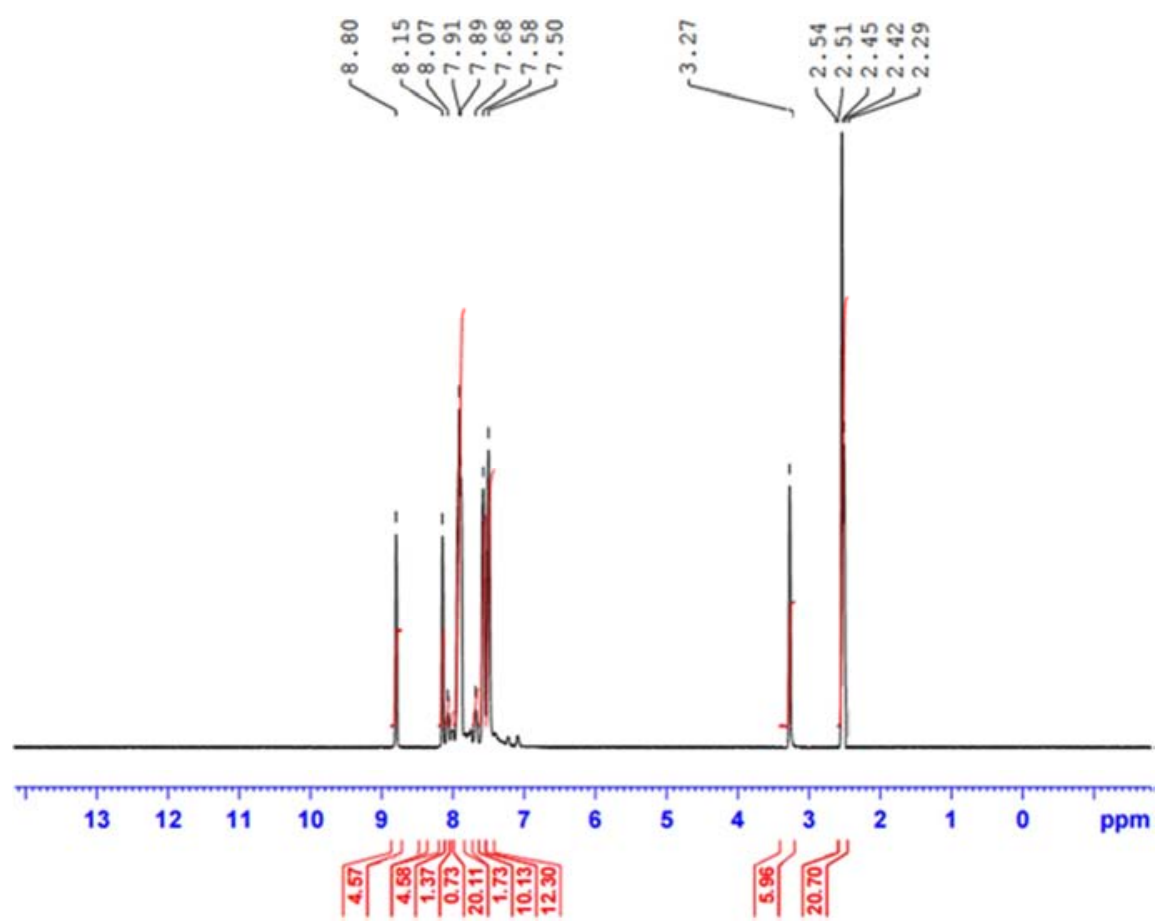

Figure 10. ${ }^{1} H$-NMR spectrum of compound $4 a$.

In the ${ }^{13} \mathrm{C}-\mathrm{NMR}$ spectrum of compound 4a "Figure 11" revealed two new signals at $\delta 171.99 \& 22.85 \mathrm{ppm}$ due to the two carbon atoms of acetyl group $\left(\mathrm{CH}_{3} \mathrm{CO}\right)$. The signals due

to the carbons of aromatic, thiazole, pyrazole rings and cyano group were noticed in the region at $\delta 156.43-114.20 \mathrm{ppm}$.

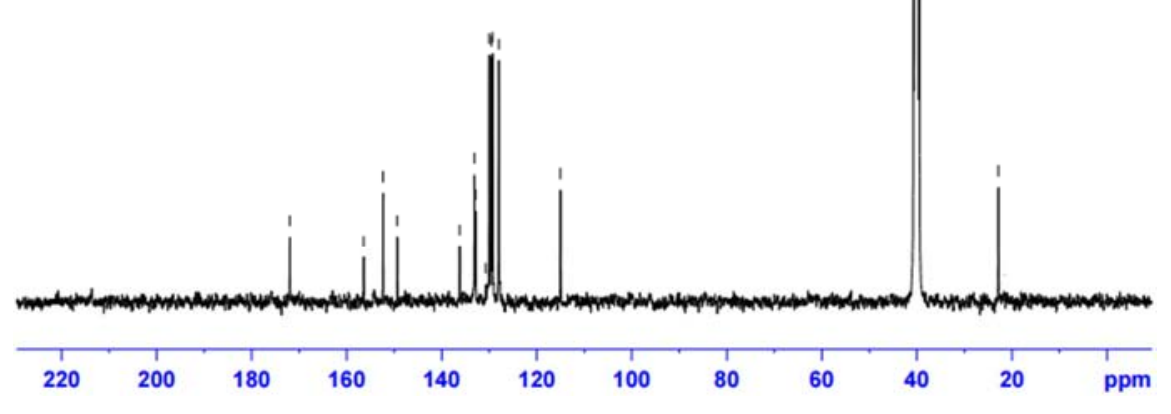

Figure 11. ${ }^{13} C$-NMR spectrum of compound $4 a$. 
${ }^{1} \mathrm{H}-\mathrm{NMR}$ spectrum of compound 6 "Figure 12" revealed the presence of a singlet signal at $\delta 8.42 \mathrm{ppm}$ demonstrated the existence of $\mathrm{CH}=\mathrm{N}$ group. Aromatic protons resonate as multiplets at around $\delta$ 7.44-8.18 ppm, singlet signal showed at $\delta 3.88 \mathrm{ppm}$ due to $-\mathrm{OCH}_{3}$ and signal showed at $\delta 11.35$ indicating the presence of $\mathrm{OH}$ group.
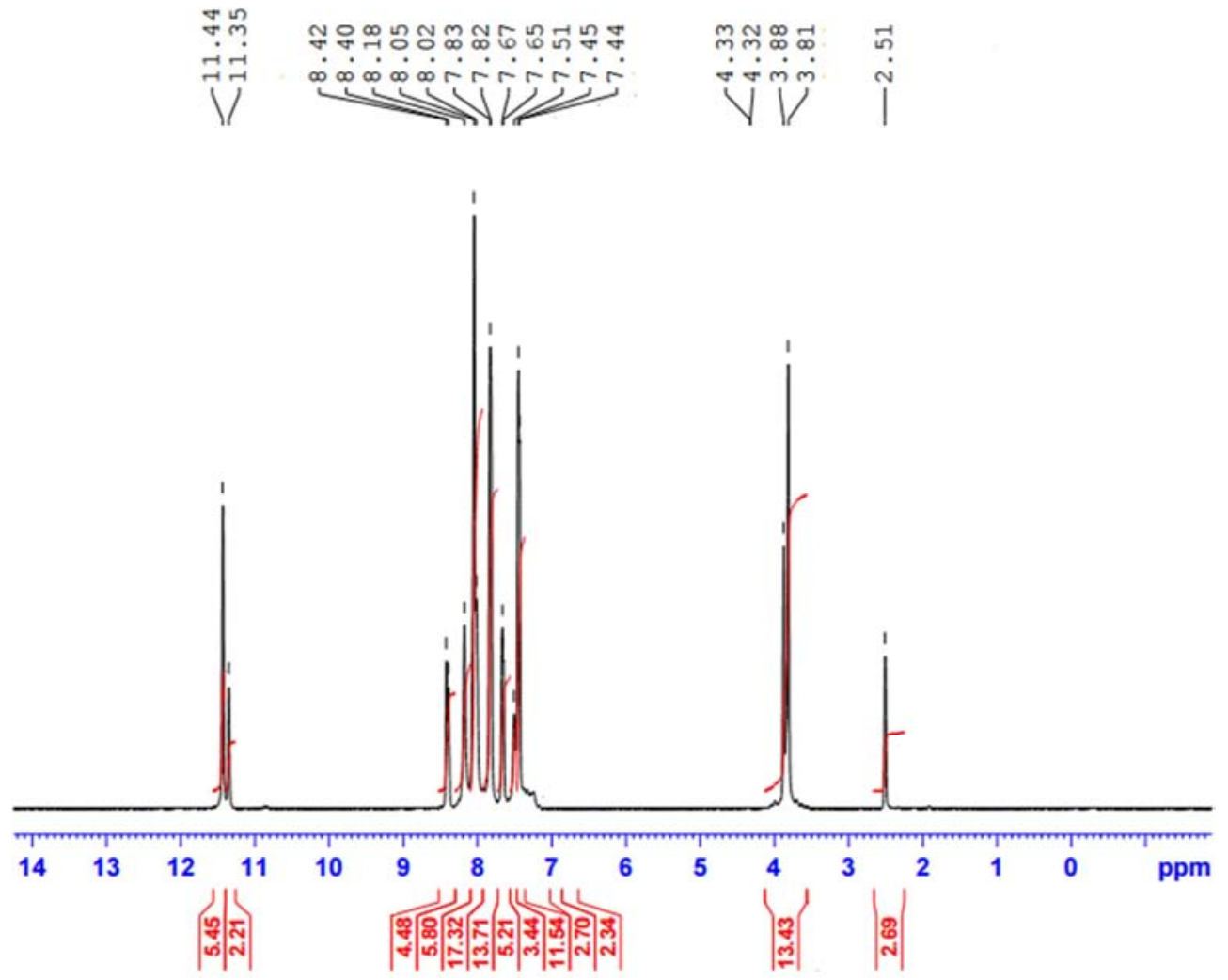

Figure 12. ${ }^{1} H$-NMR spectrum of compound 6.
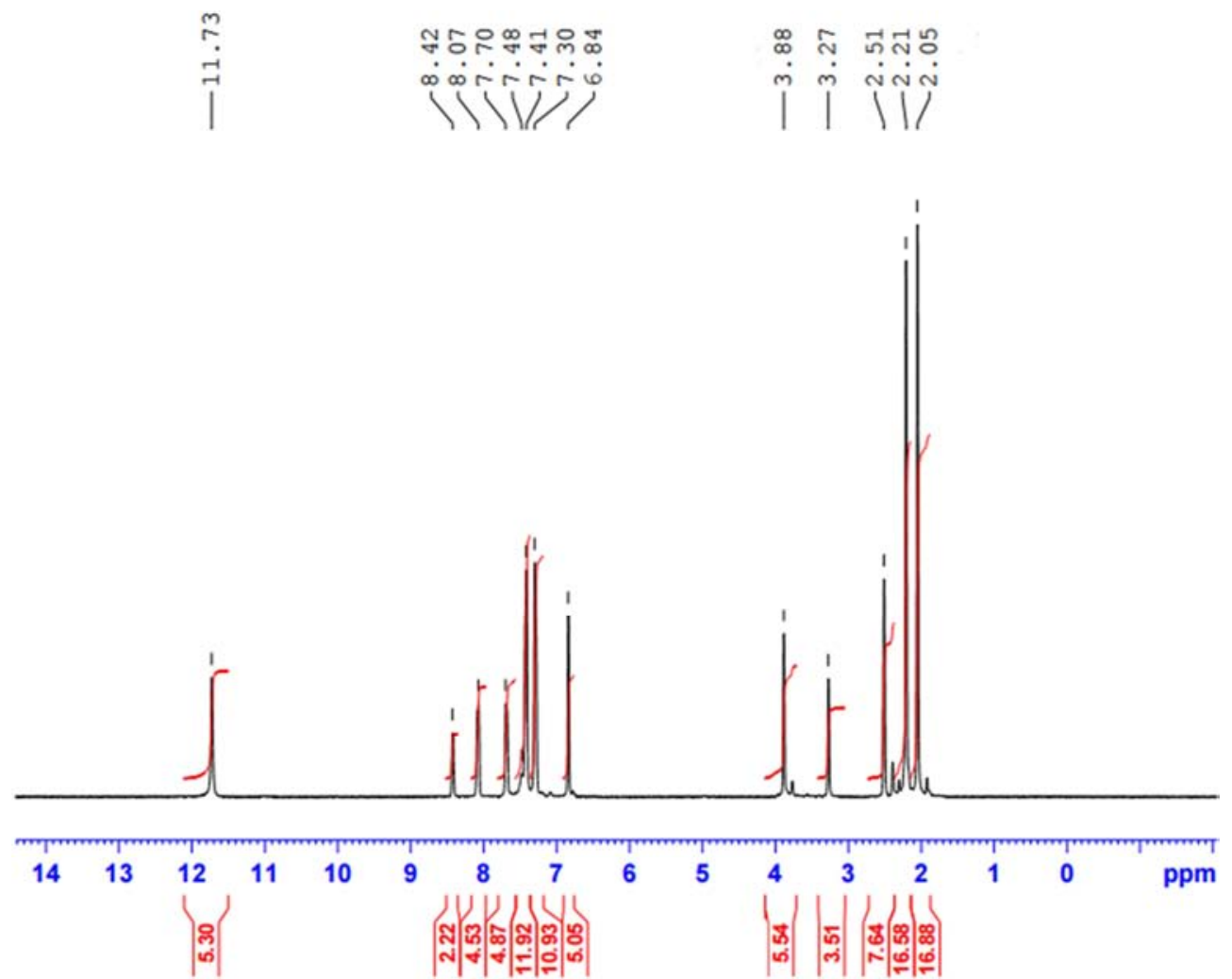

Figure 13. ${ }^{1} H$-NMR spectrum of compound 7. 

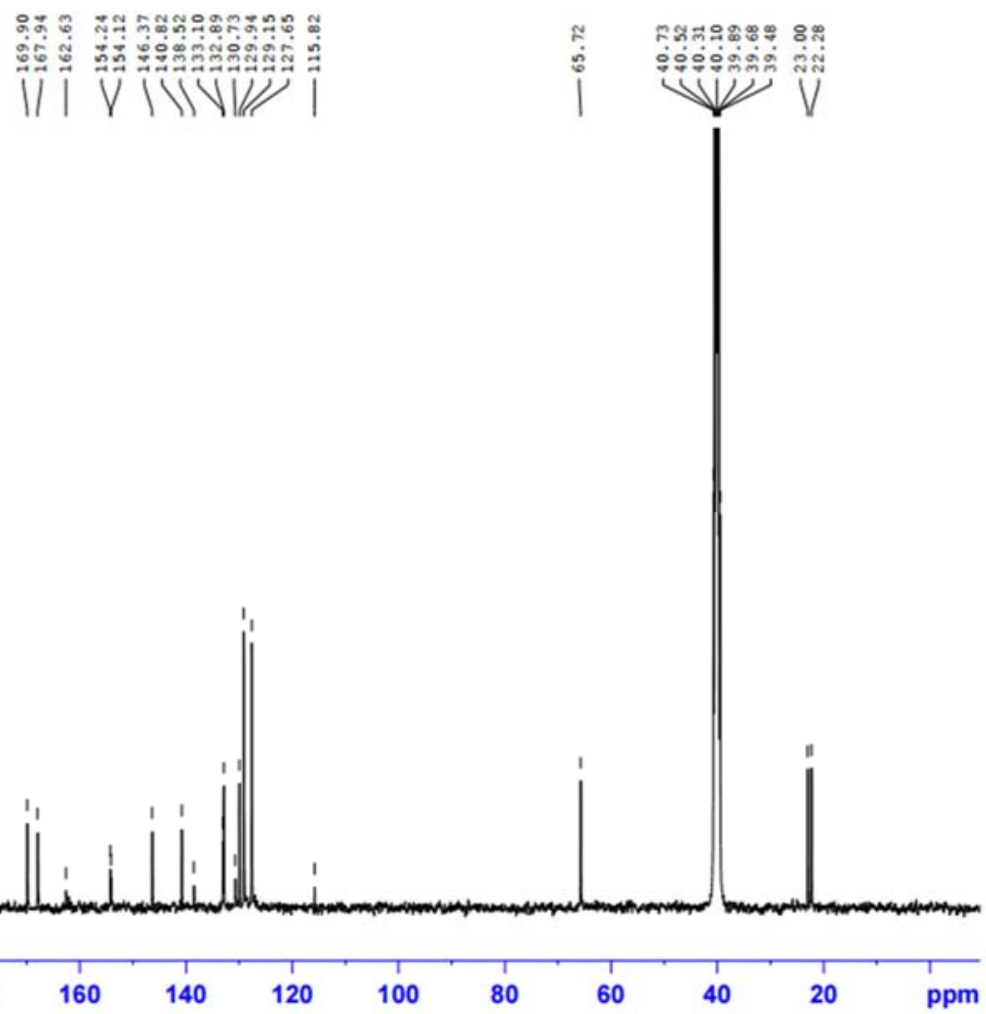

Figure 14. ${ }^{13} \mathrm{C}-\mathrm{NMR}$ spectrum of compound 7 .

On the other hand, ${ }^{1} \mathrm{H}-\mathrm{NMR}$ spectrum of compound 7 "Figure 13" exhibited signal at $\delta 2.21 \mathrm{ppm}$ due to $\mathrm{CH}_{3} \mathrm{CO}$ group, a singlet signal showed at $\delta 3.88 \mathrm{ppm}$ represented $\mathrm{OCH}_{3}$ group, in addition the aromatic multiplets in the region $\delta$ 6.84-8.07 ppm, signal showed at $\delta 11.73$ due to $\mathrm{OH}$ group. ${ }^{13} \mathrm{C}-\mathrm{NMR}$ spectrum of compound 7 "Figure 14" displayed signal at $\delta 167.94 \mathrm{ppm}$ represented to $\mathrm{C}=\mathrm{O}$ group, signals showed around $\delta$ 154.24-127.65 ppm corresponding to aromatic and pyrazole ring, signal resonating at $\delta 65.72$ due to $-\mathrm{OCH}_{3}$ and signal showed at $\delta 23 \mathrm{ppm}$ stand for $\mathrm{CH}_{3}$ group.

\subsection{Biological Assay}

\subsubsection{In vitro Anti-leukemia Activity}

Compounds 3-9 were checked for their anti-proliferative activity against leukemia HL-60 human cancer cell line by means of MTT assay method. Doxorubicin (Dox) was employed as positive reference. The $\mathrm{IC}_{50}$ values $(\mu \mathrm{M})$ of the tested compounds and reference compound are mentioned in "Table 1" and represented graphically in "Figure 15". Compounds 4, 6 and 9 (4c) were the most active against Leukemia HL-60. The $\mathrm{IC}_{50}$ values of them were less than 5 $\mu \mathrm{M}$ in the range of $1.35-4.78 \mu \mathrm{M}$. In addition, compounds 3 and 5 showed less antiproliferative activity against Leukemia HL-60 cells with $\mathrm{IC}_{50}$ values in the range 5.39-8.82 $\mu \mathrm{M}$. Structurally, pyrazole derivatives were the most active with increasing activity observed more than pyrazole containing thiazole moiety. Moreover, compound $N$ - (3- methoxy-2hydroxybenzal) -3- ( $p$-chlorophenyl)-4- cyano-5-oxopyrazol1-thiocarboxamide (6) possessed the highest cytotoxic activity with $\mathrm{IC}_{50}$ value of $1.35 \mu \mathrm{M}$ compared with Dox $\mathrm{IC}_{50}$ value of $2.02 \mu \mathrm{M}$. Additionally, it was observed that, a decrease in the cytotoxic activity was shown as acetylation to the pyrazole ring, regardless of the substitution. In conclusion, it is clear that compounds 4,6 and 9 (4c) were the most potent active compounds. Compound 6 gave the highest cytotoxicty $\left(\mathrm{IC}_{50}\right.$ value is $\left.1.35 \mu \mathrm{M}\right)$ compared with the value of Dox $\left(\mathrm{IC}_{50}\right.$ value is $\left.2.02 \mu \mathrm{M}\right)$.

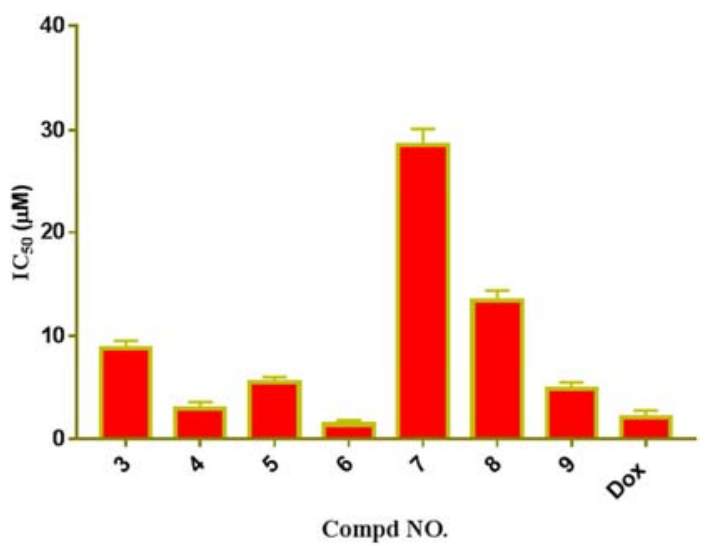

Figure 15. Graphical presentation of the antitumor activity of the prepared compounds 3-9 over Leukemia HL-60 cell line.

Table 1. In vitro antitumor activity of pyrazole derivatives 3-9 over Leukemia HL-60 cell line. Records are represented as the mean \pm three experiments.

\begin{tabular}{ll}
\hline \multirow{2}{*}{ Compound No. } & IC 5 values $(\boldsymbol{\mu M})$ \\
\cline { 2 - 2 } & HL-60 \\
\hline 3 & $8.82 \pm 0.72$ \\
4 & $2.91 \pm 0.13$ \\
5 & $5.39 \pm 0.24$ \\
6 & $1.35 \pm 0.14$ \\
\hline
\end{tabular}




\begin{tabular}{ll}
\hline \multirow{2}{*}{ Compound No. } & IC $_{\mathbf{5 0}}$ values $(\boldsymbol{\mu M})$ \\
\cline { 2 - 2 } & $\mathbf{H L - 6 0}$ \\
\hline 7 & $28.54 \pm 1.56$ \\
9 & $13.4 \pm 1.04$ \\
Dox & $4.78 \pm 0.24$ \\
\hline
\end{tabular}

\subsubsection{Analysis of Cell Cycle}

Compound 6 had the highest promising cytotoxicty against Leukemia HL-60 cell line. So it was selected for extra investigation concerning its mechanism of cell proliferation inhibition mechanism. To discover the correlation between

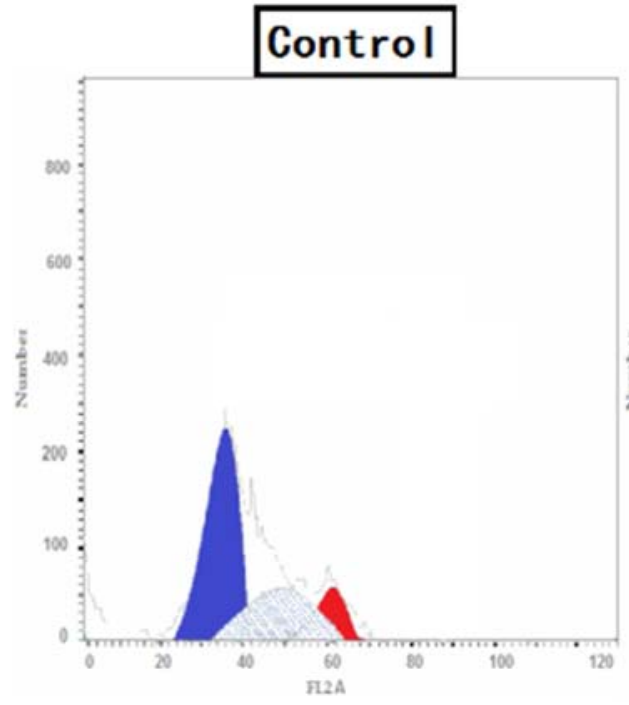

the cell cycle progression and anticancer effect, DNA flow cytometric assay by means of propidium iodode (PI) in Leukemia HL-60 cells after handling with compound 6 on its $\mathrm{IC}_{50}$ concentration dose for $24 \mathrm{hrs}$. "Figure 16". It is observed that compound 6 increased the percentage of $\mathrm{G} 2 / \mathrm{M}$ phase from $11.05 \%$ to $39.22 \%$ compared with the untreated control. This increase was accompanied by a decrease in the other states of the cell cycle profile in Leukemia HL-60. This information recommended that, compound 6 evidently increased the percentage of $\mathrm{G} 2 / \mathrm{M}$ phase. This leads to cell growth arrest in leukemia HL-60 cells.

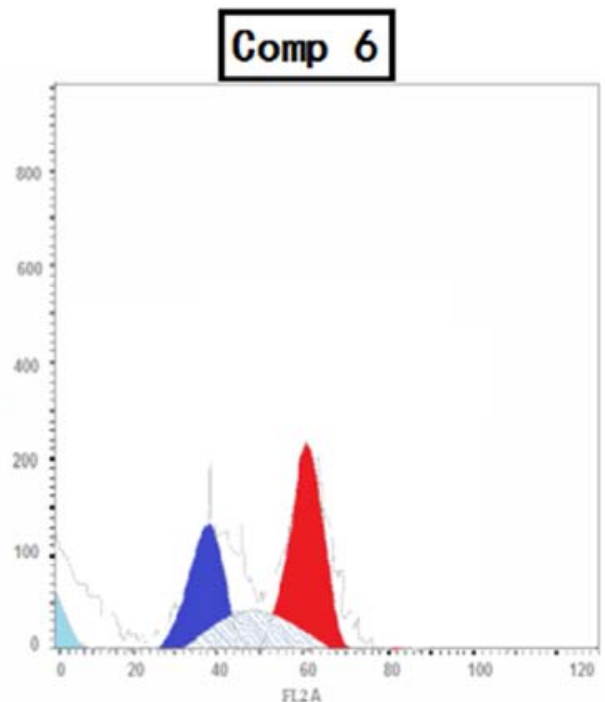

Figure 16. Cell cycle distribution of human leukemia HL-60 cell line induced by compound 6. Cells were rigid and detected with PI staining to evaluate DNA content by flow cytometry.

\subsubsection{Apoptosis Detection Assay}

According to cell death caused by compound 6, a biparamertric cytofluorimetric was analyzed using PI and Annexin-V-FITC which was in Leukemia HL-60 cells subsequent to treatment with compound 6 at its $\mathrm{IC}_{50}$ value for $24 \mathrm{hrs}$ "Figure 17". It's revealed that compound 6 increases the value of total apoptosis compared with unprocessed control group. The value of early apoptosis was increased from $1.11 \%$ to $6.74 \%$ compared with the non-treated control group. Additionally, compound 6 can increase the percentage of late apoptosis from $0.31 \%$ to $4.31 \%$ compared with untreated control. This result recommended the interest of compound 6 in the apoptosis of Leukemia HL-60 cellsinduced cell death.
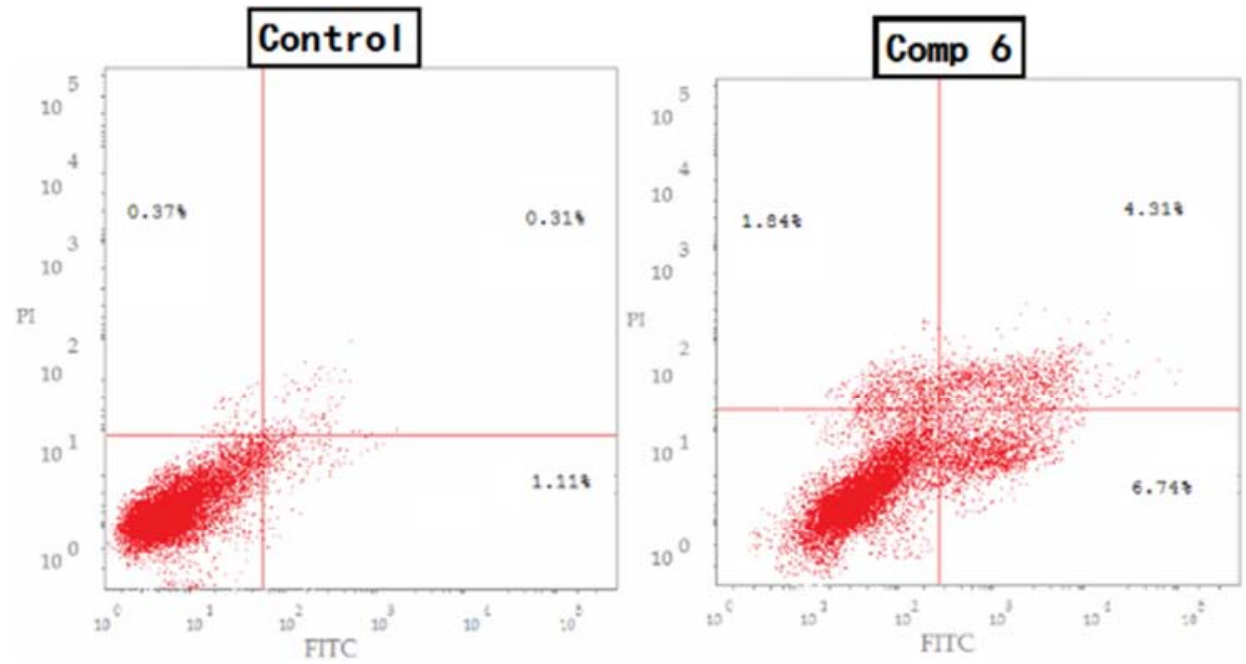

Figure 17. Apoptosis effect of compound 6 on human leukemia HL-60 cell line. Apoptotic cells were checked with Annexin-V-FITC staining after incubating with compound 6 for 24 hrs. 


\subsubsection{Assay of Topoisomerase II}

Topoisomerase II (Topo II) is an enzyme which affects on the topology of DNA and acting a vital during cell division involving DNA replication, transcription, segregation and recombination. In this study, compound 6 was evaluated for Topo II inhibition activity $\mathrm{IC}_{50}$ value to evaluate whether the most active molecule was strong Topo II inhibitor. Five dose Topo II inhibition attempt was achieved by human DNA Topoisomerase II (Topo II) ELISA screening kit. Etoposide served as positive control in this study. As illustrated in "Figure 18", the Topo II inhibition activity assay revealed that compound 6 was efficient in inhibiting the Topo II activity with $\mathrm{IC}_{50}$ value $56.04 \mathrm{nM}$ compared with etoposide which had $\mathrm{IC}_{50}$ value $41.11 \mathrm{nM}$. This result indicated that, compound 6 cytotoxic activity is mainly due to its potent DNA Topo II inhibition activity.

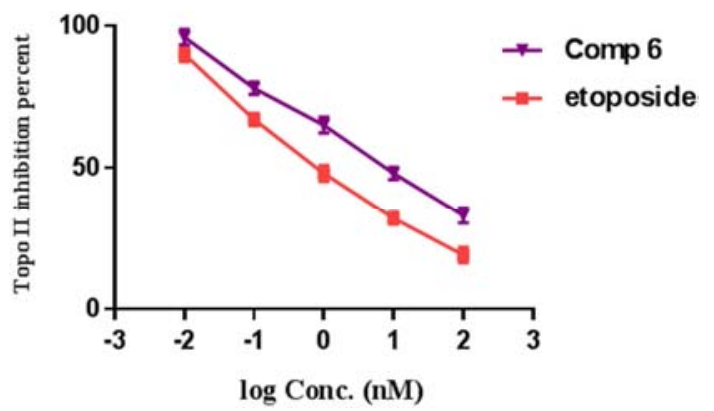

Figure 18. In vitro DNA Topo II inhibition activity of compound 6 and etoposide.

\section{Experimental Section}

\subsection{Chemistry}

Melting points were measured in open capillary tubes by Electrothermal digital melting point apparatus and are uncorrected. ${ }^{1} \mathrm{H}-\mathrm{NMR}$ and ${ }^{13} \mathrm{C}-\mathrm{NMR}$ (400 MHz) spectra were recorded in DMSO-d6 on a Bruker 400 DRX-Avance NMR spectrometer using of TMS as internal standard and chemical shifts are expressed in $\delta(\mathrm{ppm})$ values. The IR spectra were recorded as KBr pellets on a Bruker (Tensor 37) FT-IR Spectrophotometer. Mass spectra were recorded on LCMS-QQQ instruments. Elemental analyses were achieved on Carlo Erba 1108 Elemental analyzer. All compounds were within $\pm 0.35 \%$ of the theoretical values. The reactions were monitored by thin-layer chromatography (TLC) on silica gel F254 aluminum sheets (Merck), and spots were visualized by UV lamp at 254-365 $\mathrm{nm}$.

Syntheses of 3-(p-chlorophenyl) -4-cyano-5hydroxypyrazol-1-thiocarboxamide (2)

A mixture of equimolar quantity of ethyl $\beta-(p-$ chlorophenyl)- $\alpha$ - cyanoacrylate $(0.01 \quad \mathrm{~mol})$ and thiosemicaebazide $(0.01 \mathrm{~mol})$ in $70 \mathrm{~mL}$ ethanol and catalytic amount of anhydrous potassium carbmate $(0.03 \mathrm{~mol})$ was heated under reflux for 3-4 hr. The development of the reaction was monitor by TLC. After finishing of the reaction, the solid product was filtered off and washed with water. The solid was then dried, and recrystallized from ethanol to give 2 as yellow crystals, m.p. $200^{\circ} \mathrm{C}$, yield $82 \%$, IR $(\mathrm{KBr}) \mathrm{v}_{\max }=$ 3437, 3281, $3165\left(\mathrm{OH}\right.$ and $\left.\mathrm{NH}_{2}\right), 1601,1526(\mathrm{C}=\mathrm{C}), 1490$ $(\mathrm{C}=\mathrm{S}), 1705(\mathrm{C}-\mathrm{O}), 2256(\mathrm{CN}) \mathrm{cm}^{-1} .{ }^{1} \mathrm{H}$ NMR $\left(\mathrm{DMSO}_{6}\right) \delta$ : $\left.7.46\left(\mathrm{NH}_{2}\right), 7.84-8.05 d d, 4 \mathrm{H}, \operatorname{Ar} \mathrm{H}\right), 11.43(\mathrm{OH}) \mathrm{ppm}$. MS: $\mathrm{m} / \mathrm{z}(\%)=280\left(\mathrm{M}^{+}+\mathrm{Z}, 7.21\right), 278\left(\mathrm{M}^{+}, 21.30\right)$. Anal. Calcd for $\mathrm{C}_{11} \mathrm{H}_{7} \mathrm{~N}_{4} \mathrm{ClOS}$ (278): C, 47.48; H, 2.52; N, 20.14. Found: C, 47.24; H, 2.25; N, 20.02 .

Syntheses of 5- hydroxyl -4- cyano- 3- (p-chlorophenyl)-1(5-arylthiazol- 2-yl) - pyrazoles (3a-c)

A mixture of equimolar quantity of substituted pyrazole 1- thiocarboxamide $(2,0.01 \mathrm{~mol})$ and aryl bromomethyl ketones (namely, $p$ - chlorophenacyl bromide, $p$-nitrophenacyl bromide and $p$ - methoxyphenacyl bromide, $0.01 \mathrm{~mol}$ ) in 70 $\mathrm{mL}$ ethanol in the existence of fused sodium acetate $(0.03$ mol) was heated under reflux for $4 \mathrm{hr}$. The reaction mixture was cooled and poured into water and neutralized with dilute hydrochloric acid (1\%). The resulting solid was filtered off, washed with water, dried and re-crystallized from ethanol to give compound 3 .

5- Hydroxyl -4- cyano- 3- (p-chlorophenyl)-1- (5- $p$ chlorophenyl-thiazol- 2-yl) - pyrazole (3a) as yellow crystals, yield $72 \%$, m.p. $172^{\circ} \mathrm{C}$. IR $(\mathrm{KBr}) v_{\max }=3331-3010$ (br-OH), 2227 (CN), 1092, $1024(\mathrm{C}-\mathrm{O}), 1605,1563(\mathrm{C}=\mathrm{C})$ $\mathrm{cm}^{-1} .{ }^{1} \mathrm{H}$ NMR (DMSO-d $\left.{ }_{6}\right) \delta: 7.39-8.05(m, 9 \mathrm{H}$, ArH and Hthiazole), $12.20(s, 1 \mathrm{H}, \mathrm{OH}) \mathrm{ppm} .{ }^{13} \mathrm{C}$ NMR (DMSO-d $\left.{ }_{6}\right) \delta$ : $168.71,154.10,149.86,140.59,134.12,134.00,133.82$, $132.87,130.71,129.92,129.36,129.06,128.31,127.70$ (carbons of aromatic, thiazole and pyrazole rings), $105(\mathrm{CN})$ ppm. MS: $\mathrm{m} / \mathrm{z}(\%)=415\left(\mathrm{M}^{+}+2,3.20\right), 413\left(\mathrm{M}^{+}, 9.60\right)$, Anal. Calcd for $\mathrm{C}_{19} \mathrm{H}_{10} \mathrm{~N}_{4} \mathrm{Cl}_{2} \mathrm{OS}$ (413): C, 55.21; H, 2.42; N, 13.56. Found: C, 55.05; H, 2.22; N, 13.28.

5- Hydroxyl -4- cyano- 3- (p-chlorophenyl)-1- (5- $p$ nitrophenyl-thiazol- 2-yl) - pyrazole (3b) as yellow crystals, yield $68 \%$, m.p. $160^{\circ} \mathrm{C}$. IR $(\mathrm{KBr}) v_{\max }=3315-3100(b r . \mathrm{OH})$, $2025(\mathrm{CN}), 1625(\mathrm{C}=\mathrm{N}), 1605,1585(\mathrm{C}=\mathrm{C}), 1103,1092(\mathrm{C}-$ O) $\mathrm{cm}^{-1} .{ }^{1} \mathrm{H}$ NMR (DMSO-d $\left.)_{6}\right) \delta: 7.45-8.33(m, 9 \mathrm{H}, \mathrm{Ar}-\mathrm{H}$ and $\mathrm{H}$-thiazole), $11.43(s, 1 \mathrm{H}, \mathrm{OH})$ ppm. Anal. Calcd for $\mathrm{C}_{19} \mathrm{H}_{10} \mathrm{~N}_{5} \mathrm{ClO}_{3} \mathrm{~S}$ (423): C, 53.90; H, 2.36; N, 16.55. Found: $\mathrm{C}$, 53.71; H, 2.18; N, 16.33.

5- Hydroxyl -4- cyano- 3- (p-chlorophenyl)-1- (6- $p$ methoxyphenyl-thiazol- 2-yl) - pyrazole (3c) as yellow crystals, yield $69 \%$, m.p. $145^{\circ} \mathrm{C}$. IR $(\mathrm{KBr}) v_{\max }=3315-3151$ (br-OH), $2258(\mathrm{CN}), 1623(\mathrm{C}=\mathrm{N}), 1605,1585(\mathrm{C}=\mathrm{C}), 1175$, $1083(\mathrm{C}-\mathrm{O}) \mathrm{cm}^{-1} .{ }^{1} \mathrm{H}$ NMR (DMSO-d $\left.{ }_{6}\right) \delta: 3.79(\mathrm{~s}, 3 \mathrm{H}$, $\left.\mathrm{OCH}_{3}\right)$, 6.97-8.04 (m, 9H, Ar-H and H-thiazole), 12.16 (br.0s, 1H, OH) ppm. MS: m/z (\%) $=410\left(\mathrm{M}^{+}+2,4.23\right), 408$ $\left(\mathrm{M}^{+}, 12.30\right)$. Anal. Calcd for $\mathrm{C}_{20} \mathrm{H}_{13} \mathrm{~N}_{4} \mathrm{ClO}_{2} \mathrm{~S}$ (408): C, 58.82; H, 3.19; N, 13.73. Found: C, 58.58; H, 3.02; N, 13.47.

Syntheses of N- (3- methoxy-2-hydroxybenzal) -3- ( $p$ chlorophenyl)-4- cyano-5-oxopyrazol-1-thiocarboxamide (6)

A mixture of equimolar quantity of compound $2(0.01 \mathrm{~mol})$ and 3-methoxy-2-hydroxybenzaldehyde $(0.01 \mathrm{~mol})$ in $30 \mathrm{~mL}$ acetic acid was heated under reflux for $2 \mathrm{hrs}$. The reaction mixture was cooled and added to water and neutralized with dilute sodium bicarbonate $(2 \%)$. The product formed was 
filtered off, washed with water, dried and purified with recystallization from ethanol to give 6 as orange crystals, yield $71 \%$, m.p. $225^{\circ} \mathrm{C}$. IR $(\mathrm{KBr}) v_{\max }=3437(\mathrm{OH}), 3280$ $(\mathrm{NH}), 2225(\mathrm{CN}), 1723(\mathrm{C}=\mathrm{O}), 1208,1089(\mathrm{C}-\mathrm{O}), 1600$, $1528(\mathrm{C}=\mathrm{C}), 1442(\mathrm{C}=\mathrm{S}) \mathrm{cm}^{-1} .{ }^{1} \mathrm{H}$ NMR $\left(\mathrm{DMSO}-\mathrm{d}_{6}\right) \delta: 3.88$ $\left(s, 3 \mathrm{H}, \mathrm{OCH}_{3}\right), 7.44-8.18(m, 7 \mathrm{H}, \mathrm{Ar}-\mathrm{H}), 8.42(s, 1 \mathrm{H}, \mathrm{CH}=\mathrm{N})$, $11.35(\mathrm{OH})$ and $11.44(\mathrm{NH}) \mathrm{ppm}$. MS: $\mathrm{m} / \mathrm{z}(\%)=414\left(\mathrm{M}^{+}+2\right.$, 3.20), $412\left(\mathrm{M}^{+}, 10.20\right)$. Anal. Calcd for $\mathrm{C}_{19} \mathrm{H}_{13} \mathrm{~N}_{4} \mathrm{ClO}_{3} \mathrm{~S}$ (412): C, 55.34; H, 3.16; N, 13.59. Found: C, 55.12; H, 3.02; N, 13.39.

General Procedure for acetylation reactions

A solution of compounds 2,3 , and $6(0.01 \mathrm{~mol})$ in $30 \mathrm{~mL}$ acetic anhydride was heated under reflux for $2 \mathrm{hrs}$, after that cooled \& poured into ice-water. The reaction mixture was kept for $24 \mathrm{hrs}$, and the producing solid was filtered, washed by water, dried and finally crystallized from ethanol to give 4,5 and 7.

5-Acetoxy- 4-cyano-3- (p-chlorophenyl) -1- (5-pchlorophenyl thiazol -2-yl) -pyrazole (4a) as pale yellow crystals, yield $67 \%$, m.p. $220^{\circ} \mathrm{C}$. IR $(\mathrm{KBr}) \mathrm{v}_{\max }=1735(\mathrm{C}=\mathrm{O})$, 1091, $1012(\mathrm{C}-\mathrm{O}), 1625(\mathrm{C}=\mathrm{N}), 1601,1585(\mathrm{C}=\mathrm{C}) \mathrm{cm}^{-1} \cdot{ }^{1} \mathrm{H}$ NMR (DMSO-d $\left.\mathrm{d}_{6}\right) \delta: 2.42\left(s, 3 \mathrm{H}, \mathrm{COCH}_{3}\right), 8.80(s, 1 \mathrm{H}, \mathrm{H}-$ thiazole) $7.50-8.15(\mathrm{~m}, 8 \mathrm{H}, \mathrm{Ar}-\mathrm{H}) \mathrm{ppm} .{ }^{13} \mathrm{C}$ NMR (DMSO$\left.\mathrm{d}_{6}\right) \delta: 171.99(\mathrm{C}=\mathrm{O}), 156.43,152.35,149.37,136.24,133.15$, $132.90,130.73,130.00,129.56,129.31,128.00$ (C of aromatic, thiazole and pyrazole rings), $115(\mathrm{CN})$ and 22.85 $\left(\mathrm{CH}_{3}\right)$ ppm. MS: $\mathrm{m} / \mathrm{z}(\%)=457\left(\mathrm{M}^{+}+2,3.25\right), 455\left(\mathrm{M}^{+}\right.$, 11.20). Anal. Calcd for $\mathrm{C}_{21} \mathrm{H}_{12} \mathrm{~N}_{4} \mathrm{Cl}_{2} \mathrm{O}_{2} \mathrm{~S}$ (455): C, 55.38; $\mathrm{H}$, 2.64; N, 12.31. Found: C, 55.09; H, 2.42; N, 12.03.

5-Acetoxy- 4-cyano-3- (p-chlorophenyl) -1- (5-pnitrophenyl thiazol -2-yl) -pyrazole (4b) as pale yellow crystals, yield $63 \%$, m.p. $230^{\circ} \mathrm{C}$. IR $(\mathrm{KBr}) v_{\max }=2228(\mathrm{CN})$, $1741(\mathrm{C}=\mathrm{O}), 1083,1041(\mathrm{C}-\mathrm{O}), 1605,1575(\mathrm{C}=\mathrm{C}) \mathrm{cm}^{-1} .{ }^{1} \mathrm{H}$ NMR (DMSO-d $\left.\mathrm{d}_{6}\right) \delta: 2.45\left(s, 3 \mathrm{H}, \mathrm{COCH}_{3}\right), 7.41-8.32(m, 8 \mathrm{H}$, Ar-H), $8.62(s, 1 \mathrm{H}, \mathrm{H}$-thiazole $) \mathrm{ppm}$. Anal. Calcd for $\mathrm{C}_{4} \mathrm{H}_{12} \mathrm{~N}_{5} \mathrm{ClO}_{4} \mathrm{~S}$ (465): C, 54.19; H, 2.58; N, 15.05. Found: C, $54.01 ; \mathrm{H}, 2.35 ; \mathrm{N}, 14.89$.

5-Acetoxy- 4-cyano-3- (p-chlorophenyl) -1- (5-pmethoxyphenyl thiazol -2-yl) -pyrazole (4c) as pale yellow crystals, yield $71 \%$, m.p. $220^{\circ} \mathrm{C}$. IR (KBr) $v_{\max }=2251(\mathrm{CN})$, $1741(\mathrm{C}=\mathrm{O}), 1125,1087(\mathrm{C}-\mathrm{O}), 1625(\mathrm{C}=\mathrm{N}), 1605,1583$ $(\mathrm{C}=\mathrm{C}) \mathrm{cm}^{-1} .{ }^{1} \mathrm{H}$ NMR $\left(\mathrm{DMSO}_{-} \mathrm{d}_{6}\right) \delta: 3.82\left(s, 3 \mathrm{H}, \mathrm{OCH}_{3}\right)$, 6.98-8.01 ( $m, 8 \mathrm{H}, \mathrm{Ar}-\mathrm{H}), 8.35$ ( $s, \mathrm{H}, \mathrm{H}-$ thiazole $), 2.43(s, 3 \mathrm{H}$, $\left.\mathrm{COCH}_{3}\right) \mathrm{ppm}$. MS: $\mathrm{m} / \mathrm{z}(\%)=452\left(\mathrm{M}^{+}+2,2.30\right), 450\left(\mathrm{M}^{+}\right.$, 7.50). Anal. Calcd for $\mathrm{C}_{22} \mathrm{H}_{15} \mathrm{~N}_{4} \mathrm{ClO}_{3} \mathrm{~S}$ (450): C, 58.67; H, 3.33; N, 12.44. Found: C, 58.44; H, 3.11; N, 12.16 .

N-Acetyl 5-Acetoxy- 4-cyano-3- (p-chlorophenyl) pyrazole -1 - thiocarboxamide (5) as pale yellow crystals, yield $68 \%$, m.p. $226^{\circ} \mathrm{C}$. IR $(\mathrm{KBr}) v_{\max }=3216(\mathrm{NH}), 2252$ $(\mathrm{CN}), 1715,1695(\mathrm{C}=\mathrm{O}), 1098,1071(\mathrm{C}-\mathrm{O}), 1625(\mathrm{C}=\mathrm{N})$, 1606, $1583(\mathrm{C}=\mathrm{C}) \mathrm{cm}^{-1} .{ }^{1} \mathrm{H}$ NMR (DMSO-d 6$) \delta: 2.05(s, 3 \mathrm{H}$, $\left.\mathrm{COCH}_{3}\right), 2.21\left(s, 3 \mathrm{H}, \mathrm{COCH}_{3}\right), 7.30-7.69(m, 4 \mathrm{H}, \mathrm{Ar}-\mathrm{H})$, $11.73(s, 1 \mathrm{H}, \mathrm{NH}) \mathrm{ppm} .{ }^{13} \mathrm{C}$ NMR $\left(\mathrm{DMSO}_{6}\right) \delta: 193.52$ $(\mathrm{C}=\mathrm{S}), 169.90,167.94 \quad(\mathrm{C}=\mathrm{O}), 154.25,146.37,140.82$, $133.10,132.89,129.54,128.16,128.47,127.65$ (C of aromatic and pyrazole rings), $115.83(\mathrm{CN}), 23.00,22.28$ $\left(\mathrm{CH}_{3}\right) . \mathrm{MS}: \mathrm{m} / \mathrm{z}(\%)=364\left(\mathrm{M}^{+}+1,0.51\right), 362\left(\mathrm{M}^{+}, 1.70\right), 320$
(100\%). Anal. Calcd for $\mathrm{C}_{15} \mathrm{H}_{11} \mathrm{~N}_{4} \mathrm{ClO}_{3} \mathrm{~S}$ (362): C, 49.72; $\mathrm{H}$, 3.04 ; N, 15.47. Found: C, 49.59; H, 2.87; N, 15.35 .

$\mathrm{N}-(m$-Methoxy- $O$-acetoxy-benzal) 5 - hydroxyl- 4- cyano3-(l-chlorophenyl)-pyrazol-1-thiocarboxamide (7) as pale orange crystals, yield $71 \%$, m.p. $180^{\circ} \mathrm{C}$. IR (KBr) $v_{\max }=3432$ (br-OH), $2256(\mathrm{CN}), 1721(\mathrm{C}=\mathrm{O}), 1088,1011(\mathrm{C}-\mathrm{O}), 1628$ $(\mathrm{C}=\mathrm{N}), 1610,1582(\mathrm{C}=\mathrm{C}), 1446(\mathrm{C}=\mathrm{S}) \mathrm{cm}^{-1} .{ }^{1} \mathrm{H}$ NMR $\left(\mathrm{DMSO}_{6}\right) \delta: 2.21\left(s, 3 \mathrm{H}, \mathrm{COCH}_{3}\right), 3.88\left(s, 3 \mathrm{H}, \mathrm{OCH}_{3}\right)$, 6.84-8.07 ( $m, 7 \mathrm{H}, \mathrm{Ar}-\mathrm{H}), 8.42(s, 1 \mathrm{H}, \mathrm{CH}=\mathrm{N}), 11.73$ (br.s, $1 \mathrm{H}, \mathrm{OH}) \mathrm{ppm} .{ }^{13} \mathrm{C} \mathrm{NMR}\left(\mathrm{DMSO}_{6}\right) \delta: 169.90(\mathrm{C}=\mathrm{S})$, $167.94(\mathrm{C}=\mathrm{O}), 154.24,146.37,140.83,138.52,133.10$, $132.89,129.94,129.15,127.65$ (C-aromatic and pyrazole ring), $115.83(\mathrm{CN}), 65.72\left(\mathrm{OCH}_{3}\right), 23.00\left(\mathrm{CH}_{3}\right)$ ppm. MS: $\mathrm{m} / \mathrm{z}(\%)=456\left(\mathrm{M}^{+}+2,0.7\right), 454\left(\mathrm{M}^{+}, 3.01\right)$. Anal. Calcd for $\mathrm{C}_{21} \mathrm{H}_{15} \mathrm{~N}_{4} \mathrm{ClO}_{4} \mathrm{~S}$ (454): C, 55.51; H, 3.30; N, 12.33. Found: C, 55.28; H, 3.09; N, 12.13.

\subsection{Biological Studies}

\subsubsection{Anti-tumor Activity Against Leukemia Cancer Cell Line (Leukemia HL-60)}

The cytotoxic activity was checked in vitro for the recently prepared compounds by using the MTT assay. Cells were plated in 96- multiwall plate $\left(10^{5}\right.$ cells/well) for $24 \mathrm{hrs}$ before handling with the compounds. Examined compounds were dissolved in dimethyl sulfoxide. Several concentrations of the compound under assessment $(10,25,50$, and $100 \mu \mathrm{M})$ were added to the cell's monolayer. Triplicate wells were arranged for each individual concentration. Monolayer cells were incubated with the compound(s) for $48 \mathrm{hrs}$ at $37^{\circ} \mathrm{C}$ and in atmosphere of $5 \% \mathrm{CO}_{2}$. After $48 \mathrm{hrs}$, cells were fixed, washed and stained with $40 \mu \mathrm{L}$ of MTT solution $(5 \mathrm{mg} / \mathrm{mL}$ of MTT in $0.9 \% \mathrm{NaCl}$ ) and was added in each well then incubated for extra $4 \mathrm{hrs}$. MTT crystals were dissolved in 180 $\mu \mathrm{L}$ of acidified isopropanol/well. The plate was shaking at room temperature, and then determining the absorbance at $570 \mathrm{~nm}$ by ELISA reader. The molar concentration requisite to inhibit $50 \%$ of cell capability $\left(\mathrm{IC}_{50}\right)$ was calculated, and compared with the reference drug doxorubicin. The surviving fractions were represented as means \pm S.E.M.

\subsubsection{Analysis of Cell Cycle for Compound 6}

Leukemia HL-60 cells, $\left(3.0 \times 10^{5}\right.$ cells/well) was incubated at $37^{\circ} \mathrm{C}$ for $12 \mathrm{hrs}$. Compound 6 was added to target cells at its $\mathrm{IC}_{50}$ concentration and left for $24 \mathrm{hrs}$. After treatment, cells were collected and fixed with $75 \%$ ethanol at $20^{\circ} \mathrm{C}$ overnight. The cells were washed with PBS followed by centrifugation and then incubated with $(10 \mathrm{mg} / \mathrm{mL})$ Rnase (Sigma, USA) and (5 mg/mL) propidium iodide (PI, Sigma) before flow cytometry analysis (FACSCalibur cytometer using Cellquest software, BD Bioscience, USA).

\subsubsection{Annexin V-FITC/PI and Detection of Apoptosis of Compound 6}

Leukemia HL-60 cells $\left(1.5 \times 10^{5}\right.$ cells/well), incubated for 12 hrs. Cells were treated with compound 6 at its $\mathrm{IC}_{50}$ value for $24 \mathrm{hrs}$. Apoptosis was determined by staining cells with FITC-conjugated Annexin-V and Propidium Iodide, and then 
analyzed by a FACSCalibur cytometer by using Cellquest software (BD Bioscience).

\subsubsection{In vitro Topoisomerase II Enzyme Inhibition Assay}

Compound 6 was selected to be examined against topo II using human DNA Topoisomerase II (Topo II) ELISA screening kit according to manufacturer's instructions. $100 \mathrm{~mL}$ of standard and sample was added per well and incubate for 2 hrs at $37^{\circ} \mathrm{C}$. Take out the liquid of each well. Add $120 \mathrm{~mL}$ of biotin-antibody to each well then incubate for $1 \mathrm{hr}$ at $37^{\circ} \mathrm{C}$. Aspirate each well and wash three times. Add $100 \mathrm{~mL}$ of horseradish Peroxidase (HRP-avidin) to each well and then incubate for $1 \mathrm{~h}$ at $37^{\circ} \mathrm{C}$. Repeat the aspiration/wash process for five times. Add $90 \mathrm{~mL}$ of 3,3',5,5'-Tetramethylbenzidine (TMB) substrate to each well and incubate for 15-30 min at $37^{\circ} \mathrm{C}$, save from light. Add $50 \mathrm{~mL}$ of stop solution to each well and find out the optical density of each well within $5 \mathrm{~min}$, using a ROBONEK P2000 ELISA reader to $450 \mathrm{~nm}$. The values of $\%$ activity versus a series of compound log concentrations $(-2 \mathrm{nM},-1 \mathrm{nM}, 0 \mathrm{nM}, 1 \mathrm{nM}, 2 \mathrm{nM})$ were then plotted using non-linear regression analysis of sigmoidal doseresponse curve. The $\mathrm{IC}_{50}$ values for compounds 6 against topo II was estimated by the concentration causing a half-maximal percent activity and the records were compared with etoposide as standard. All experiments were made in triplicates.

\section{Conclusion}

The purpose of the current work was to syntheses and study In vitro antileukemia cancer activity of some novel pyrazole derivatives (2 and 5) and pyrazoles carrying the biologically active thiazole moieties at 1-position. All the synthesized compounds were established by using IR, MS, ${ }^{1} \mathrm{H},{ }^{13} \mathrm{C}$ NMR and elemental analyses. All of the synthesized compounds were monitored for their cytotoxic activity against Leukemia HL-60 cell line by using Doxorubicin as positive control. The results demonstrated that compound 6 was the most potent cytotoxic activity with $\mathrm{IC}_{50}$ value $1.35 \mu \mathrm{M}$. Exhaustive mechanism studies for cell cycle analysis of compound 6 were exposed cell cycle detain at G2/M phase and pre-G1 apoptosis. Topoisomerase II inhibition activity assay confirmed that compound 6 is a potent DNA Topoisomerase II inhibitor.

\section{Declaration of Interest Section}

Author has no declarations of interest to report

This research did not receive any specific grant from funding agencies in the public, commercial, or not-for-profit sectors.

\section{References}

[1] Achson, A. An Introduction to the Chemistry of Heterocyclic Compounds, third ed., Willey-Intersciences, 2009.

[2] Hamad, A. J., A. J. Kh. Atia, M. F. Al-Marjani, S. A. K. Redha, I. AL-Bayti and E. H. Batah (2019). Synthesis and anti-microbial activity of new 4-carboxylic imidazole derivatives. Journal of Pharmaceutical Sciences and Research
$11(1), 131-135$.

[3] Wipf, P. and T. D. Hopkins (2005). Total synthesis and structure validation of (+)-bistramide C. Chemical Communications 3421-3423.

[4] Rudolph, M. J., C. R. Illig, N. L. Subasinghe, K. J. Wilson, J. B. Hoffman, T. Randle, D. Green, C. J. Molloy, R. M. Soll, F. Lewandowski, M. Zhang, R. Bone, J. C. Spurlino, I. C. Deckman, C. Manthey, C. Sharp, D. Maguire, B. L. Grasberger and Zh. Zhou (2002). Design and Synthesis of 4,5Disubstituted-thiophene-2-amidines as Potent Urokinase Inhibitors. Bioorganic \& Medicinal Chemistry Letters 12 (3), 491-495.

[5] Weiß K. M., S. Wei and S. B. Tsogoeva (2011). Novel one-pot process for the synthesis of 1,3-thiazoles via organocatalysed epoxidation of nitro-olefins. Organic and Biomolecular Chemistry 9, 3457-3461.

[6] An T. N. M., M. A. Kumar, S. H. Chang, M. Y. Kim, J. A. Kim and K. D. Lee (2014). Real-time Monitoring of Colloidal Nanoparticles using Light Sheet Dark-field Microscopy Combined with Microfluidic Concentration Gradient Generator (?FCGG-LSDFM). Bulletin Korean Chemical Society 35 (6), 1619-1624.

[7] Chimenti F., A. Bolasco, D. Secci, P. Chimenti, A. Granese, S. Carradori, M. Yanez, F. Orallo, F. Ortuso and S. Alcaro (2012). Investigations on the 2-thiazolylhydrazyne scaffold: synthesis and molecular modeling of selective human monoamine oxidase inhibitors. Bioorgic Medicinal Chemistry 18 (15), 5715-5723.

[8] Dondoni A. (2010). Heterocycles in organic synthesis: thiazoles and triazoles as exemplar cases of synthetic auxiliaries. Organic and Biomolecular Chemistry 8, 33663385 .

[9] Khare R., J. Sharma and A. Sharma (2016). Synthesis, characterization, and antibacterial activity of some thiazoles derived from allyl thioureas. Russian Journal of General Chemistry 86, 3, 702-707.

[10] Chimenti F., R. Fioravanti, A. Bolasco, F. Manna, P. Chimenti, D. Secci, F. Rossi, P. Turini, F. Ortuso, S. Alcaro and M. C. Cardia (2008). Synthesis, molecular modeling studies and selective inhibitory activity against MAO of N1-propanoyl3,5-diphenyl-4,5-dihydro-(1H)-pyrazole derivatives. European Journal of Medicinal Chemistry 43 (10), 2262-2267.

[11] Suh C. W. and D. Y. Kim (2014). Enantioselective One-Pot Synthesis of Ring-Fused Tetrahydroquinolines via Aerobic Oxidation and 1,5-Hydride Transfer/Cyclization Sequences. Organic Letters 16 (20), 5374-5377.

[12] Bhongade B. A., S. Talath, R. A. Gadad and A. K. Gadad (2016). Biological activities of imidazo[2,1b] $[1,3,4]$ thiadiazole derivatives: A review. Journal Saudi Chemical Society 20, S463-S475.

[13] Rudolph J., H. Theis, R. Hanke, R. Endermann, L. Johannsen and F. M. Geschke (2014). Synthesis, Anticancer and Antioxidant Activity of Novel 2,4-Disubstituted Thiazoles. Bulletin of the Korean Chemistry Society 35 (6), 1619-1624.

[14] Gomha S. M., A. Sayed, S. A. Ahmed and A. O. Abdelhamid (2015). Synthesis and Cytotoxicity Evaluation of Some Novel Thiazoles, Thiadiazoles, and Pyrido[2,3- $d][1,2,4]$ triazolo[4,3a]pyrimidin-5(1H)-ones Incorporating Triazole Moiety. Molecules 20, (1) 1357-1376. 
[15] Siddiqui N., F. Arshad, W. Ahsan and M. S. Alam (2009). Thiazoles: a valuable insight into the recent advances and biological activities. International Journal of Pharmaceutical Sciences and Drug Research 1 (3), 136-143.

[16] Sayyed M., S. Mokle, M. Bokhare, A. Mankar, S. Surwase, S. Bhusare and Y. Vibhute (2006). Synthesis of some new 2, 3diaryl-1, 3-thiazolidin-4-ones as antibacterial agents. Arkivoc ii, $187-192$.

[17] Sudbeck E. A., C. Mao, R. Vig, T. K. Venkatachalam, L. Tuel-Ahlgren and F. M. Uckun (1998). Structure-Based Design of Novel Dihydroalkoxybenzyloxopyrimidine Derivatives as Potent Nonnucleoside Inhibitors of the Human Immunodeficiency Virus Reverse Transcriptase. Antimicrobial Agents and Chemotherapy 42 (12), 32253233.

[18] Trivedi A. R., A. B. Siddiqui and V. H. Shah (2008). Design, synthesis, characterization and antitubercular activity of some 2-heterocycle-substituted phenothiazines. Arkivoc ii, 210 217.

[19] Bell F. W., A. S. Cantrell, M. Hoegberg, S. R. Jaskunas, N. G. Johansson, C. L. Jordan, M. D. Kinnick, P. Lind and J. M. Morin (1995). Phenethylthiazolethiourea (PETT) Compounds, a New Class of HIV-1 Reverse Transcriptase Inhibitors. 1. Synthesis and Basic Structure-Activity Relationship Studies of PETT Analogs. Journal of Medicinal Chemistry 38 (25), 4929-4936.

[20] Holla B. S., K. V. Malini, B. S. Rao, B. K. Sarojini and N. S. Kumari (2003). Synthesis of some new 2,4-disubstituted thiazoles as possible antibacterial and anti-inflammatory agents. European Journal of Medicinal Chemistry 38, 313318 .

[21] Sharma R. N., F. P. Xaurer, K. K. Vasu, S. C. Chaturvedi and S. S. Pancholi (2009). Synthesis of 4-benzyl-1, 3-thiazole derivatives as potential anti-inflammatory agents: an analogue-based drug design approach. Journal Enzyme Inhibition Medicinal Chemistry 24 (3), 890-897.

[22] Kumar S., V. Saini, I. K. Maurya, J. Sindhu, M. Kumari, R. Kataria and V. Kumar (2018). Design, synthesis, DFT, docking studies and ADME prediction of some new coumarinyl linked pyrazolylthiazoles: Potential standalone or adjuvant antimicrobial agents. PLoS ONE 13 (4), e0196016.

[23] Kashyap S. J., V. K. Garg, P. k. Sharma, K. Nitin, D. Rupesh and J. K. Gupta (2012). Thiazoles: having diverse biological activities. Medicinal Chemistry Research 21, 2123-2123.

[24] Karegoudar P., M. S. Karthikeyan, D. J. Prasad, M. Mahalinga, B. S. Holla and N. S. Kumari (2008). Synthesis of some novel 2,4-disubstituted thiazoles as possible antimicrobial agents. European Journal of Medicinal Chemistry 43, 261-267.

[25] Shih M. H. and K. F. Ying (2004). Syntheses and evaluation of antioxidant activity of sydnonyl substituted t hiazolidinone and thiazoline derivatives. Bioorganic and Medicinal Chemistry 12, 4633-4643.

[26] Shiradkar M., G. V. S. Kumar, V. Dasari, S. Tatikonda, K. C. Akula and R. Shah (2007). Clubbed triazoles A novel approach to antitubercular drugs. European Journal of Medicinal Chemistry 42, 807-816.

[27] Amin K. M., A. D. E. Rahman and Y. A. Al-Eryani (2008). Synthesis and preliminary evaluation of some substituted coumarins as anticonvulsant agents. Bioorganic and Medicinal Chemistry 16, 5377-5388.

[28] Gomha S. M., S. M. Riyadh, I. M. Abbas and M. A. Bauomi (2013). Synthetic utility of ethylidene-thiosemicarbazide: Synthesis and and anti-cancer activity of 1,3-thiazines and thiazoles with imidazole moiety. Heterocycles 87, 341-356.

[29] Gomha S. M., T. A. Salah, H. M. E. Hassaneen, H. Abdel-aziz and M. A. Khedr (2016). Synthesis, characterization and molecular docking of novel bioactive thiazolyl-thiazole derivatives as promising cytotoxic antitumor drug. Molecules $21,1-17$.

[30] Gomha S. M., S. M. Riyadh, E. A. Mahmmoud and M. M. Elaasser (2015). Chitosan-grafted-poly(4-vinylpyridine) as a novel copolymer basic catalyst for synthesis of arylazothiazoles and 1,3,4-thiadiazoles under microwave irradiation. Chemistry of Heterocyclic Compounds 51, 1030 1038.

[31] Gomha S. M., M. G. Badrey and M. M. Edrees, (2016). Heterocyclization of a bis-thiosemicarbazone of 2,5-diacetyl3,4-disubstituted-thieno[2,3-b]thiophenebisthiosemicarbazones leading to bis-thiazoles and bis-1,3,4thiadiazoles as anti-breast cancer agents. Journal of Chemical Research 40, 120-125.

[32] Gomha S. M., Y. H. Zaki and A. O. Abdelhamid (2015). Utility of 3-acetyl-6-bromo-2H-chromen-2-one for synthesis of new heterocycles as potential anticancer agents. Molecules 20, 21826-21839.

[33] Dawood K. M., H. A. Gawad, E. A. Rageb, M. Ellithey and H. A. Mohamed, (2006). Synthesis, anticonvulsant, and antiinflammatory evaluation of some new benzotriazole and benzofuran-based heterocycles. Bioorganic and Medicinal Chemistry 14, 3672-3680.

[34] Gomha S. M., M. M. Edrees and F. M. A. Altalbawy (2016). Synthesis and Characterization of Some New Bis-PyrazolylThiazoles Incorporating the Thiophene Moiety as Potent AntiTumor Agents. International journal of Molecular Sciences $17,1499$.

[35] Akbas E. and I. Berber (2005). Antibacterial and antifungal activities of new pyrazolo[3,4-d]pyridazin derivatives, European Journal of Medicinal Chemistry 40, 401-405.

[36] Ozdemir A., G. Turan-Zitouni, Z. A. Kaplancıklı, G. Revial and K. Guven (2007). Synthesis and antimicrobial activity of 1-(4-aryl-2-thiazolyl)-3-(2-thienyl)-5-aryl-2-pyrazoline derivatives. European Journal of Medicinal Chemistry 42, 403-409.

[37] Manfredini S., R. Bazzanini, P. G. Baraldi, M. Guarneri, D. Simoni, M. E. Marongiu, A. Pani, P. L. Colla and E. Tramontano (1992) Pyrazole-related nucleosides. Synthesis and antiviral/antitumor activity of some substituted pyrazole and pyrazolo[4,3-d]-1,2,3-triazin-4-one nucleosides, Journal of Medicinal Chemistry 35, 917-924.

[38] Noell C. W. and C. C. Cheng (1971). Pyrazoles. 4. Analogs of 3-(3,3-dimethyl-1-triazeno)pyrazole-4-Carboxamide. Journal of Medicinal Chemistry 14, 1245-1246.

[39] Abdel-Aziz M., G. A. Abuo-Rahma and A. A. Hassan (2009). Synthesis of novel pyrazole derivatives and evaluation of their antidepressant and anticonvulsant activities. European Journal of Medicinal Chemistry 44, 3480-3487. 
[40] M. Shaharyar, A. A. Siddiqui, M. M. Ali, D. Sriram and P. Yogeeswari (2006). Synthesis and in vitro antimycobacterial activity of N1-nicotinoyl-3-(-40-hydroxy-30-methyl phenyl)5-[(sub)phenyl]-2-pyrazolines. Bioorganic and Medicinal Chemistry Letters 16, 3947-3949.

[41] Ozdemir Z., H. B. Kandilici, B. Gumusel, U. Calis and A. Bilgin (2007). Synthesis and studies on antidepressant and anticonvulsant activities of some 3-(2-furyl)-pyrazoline derivatives. European Journal of Medicinal Chemistry 42, 373-379.

[42] Hassan S. Y. (2013). Synthesis, antibacterial and antifungal activity of some new pyrazoline and pyrazole derivatives. Molecules 3, 2683-2711.

[43] Turan-Zitouni G., A. Ozdemir and K. Guven (2005). Synthesis of some 1[(N,N-disubstitutedthiocarbamoylthio)acetyl]-3-(2-thienyl)-5-aryl-2-prazoline derivatives and investigation of their antibacterial and antifungal activities. Archiv der Pharmazie 338, 96-104.

[44] Pathak R. B., P. T. Chovatia and H. H. Parekh (2012). Synthesis, antitubercular and antimicrobial evaluation of 3-(4chlorophenyl)-4-substituted pyrazole derivatives. Bioorganic and Medicinal Chemistry Letters 22, 5129-5133.

[45] Kreutzberger A. and K. Kolter (1986). Antiviral agents. XXVII: Aminomethynylation of 5-oxo-2-pyrazoline-3carboxylic acid derivatives. Archiv der Pharmazie 319, 18-25.

[46] Flora F., H. H. Hosni and A. S. Girgis (2006). Novel bis(1acyl-2-pyrazolines) of potential anti-inflammatory and molluscicidal properties. Bioorganic and Medicinal Chemistry 14, 3929-3937.

[47] Gomha S. M., S. M. Riyadh and M. M. Abdalla (2015). Solvent-drop grinding method: Efficient synthesis, DPPH radical scavenging and anti-diabetic activities of chalcones, bis-chalcones, azolines, and bis-azolines. Current Organic Synthesis $12,220-228$.

[48] Abid M. and A. Azam (2005). 1-N-substituted thiocarbamoyl3-phenyl-2-pyrazolines: Synthesis and in vitro antiamoebic activities. European Journal of Medicinal Chemistry 40, 935942.

[49] Karrouchi Kh., S. Radi, Y. Ramli, J. Taoufik, Y. N. Mabkhot, F. A. Al-aizari and M. Ansar (2018). Synthesis and Pharmacological Activities of Pyrazole Derivatives: A Review. Molecules 23, 134.

[50] Palomer A., F. Cabre, J. Pascual, J. Campos, M. A. Trujillo, A. Entrena, M. A. Gallo, L. Garcia, D. Mauleon and A. Espinosa (2002). Identification of novel cyclooxygenase-2 selective inhibitors using pharmacophore models. Journal of Medicinal Chemistry 45, 1402-1411.

[51] Abid M. and A. Azam (2006). Synthesis, characterization and antimoebic activity of 1-(thiazolo[4,5-b]-quinoxalin-2-yl)-3phenyl-2-pyrazoline derivatives. Bioorganic and Medicinal Chemistry Letters. 16, 2812-2816.

[52] Ozdemir Z., H. B. Kandilci, B. Gumusel, U. Calis and A. A. Bilgin (2007). Synthesis and studies on antidepressant and anticonvulsant activities of some 3-(2-furyl)-pyrazoline derivatives. European Journal of Medicinal Chemistry 42, 373-379.

[53] Wustrow D. J., T. Capiris, R. Rubin, J. A. Knobelsdorf, H. Akunne, M. D. Davis, R. MacKenzie, T. A. Pugsley, K. T.
Zoski, T. G. Heffner and L. D. Wise (1998). Pyrazolo[1,5a]pyrimidine CRF-1 receptor Antagonists. Bioorganic and Medicinal Chemistry Letters 18, 2067-2070.

[54] Penning T. D., J. J. Talley, S. R. Bertenshaw, J. S. Carter, P. W. Collins, S. Docter, M. J. Graneto, L. F. Lee, J. W. Malecha, J. M. Miyashiro, R. S. Rogers, D. J. Rogier, S. S. Yu, G. D. Anderson, E. G. Burton, J. N. Cogburn, S. A. Gregory, C. M. Koboldt, W. E. Perkins, K. Seibert, A. W. Veenhuizen, Y. Y. Zhang and P. C. Isakson (1997), Pyrazolo[1,5-a]pyrimidine CRF-1 receptor antagonists. Journal of Medicinal Chemistry $40,1347-1365$.

[55] Desai N. C. and M. J Bhatt (2016). Optimized Synthesis of Novel Pyrazole Based Thiazole Derivatives and their Antimicrobial Evaluation. International Letters of Chemistry. Physics and Astronomy 66, 109-118.

[56] Farag A. M., A. S. Mayhoub, S. E. Barakat and A. H. Bayomi (2008). Regioselective synthesis and antitumor screening of some novel N-phenylpyrazole derivatives. Bioorganic Medicinal Chemistry 16, 881-889.

[57] Xia Y., C. D. Fan, B. X. Zhao, J. Zhao, D. S. Shin and J. Y. Miaob (2008). Synthesis and structure-activity relationships of novel 1-arylmethyl-3-aryl-1H-pyrazole-5-carbohydrazide hydrazone derivatives as potential agents against A549 lung cancer cells. European Journal of Medicinal Chemistry 43 (11), 2347-2353.

[58] Xia Y., Z. W. Dong, X. Ge, N. Meng, D. S. Shin and J. Y. Miaob (2007). Synthesis and structure-activity relationships of novel 1-arylmethyl-3-aryl-1H-pyrazole-5-carbohydrazide derivatives as potential agents against A549 lung cancer cells. Bioorganic Medicinal Chemistry 15 (22), 6893-6899.

[59] El-Enany M. M., M. M. Kamel, O. M. Khalil and H. B. ElNassan (2011). Synthesis and antitumor activity of novel pyrazolo[1,5-a]pyrimidine derivatives. European Journal of Chemistry 2 (3), 331-336.

[60] Manetti F., C. Brullo, M. Magnani, F. Mosci, B. Chelli, E. Crespan, S. Schenone, A. Naldini, O. Bruno, M. L. Trincavelli, G. Mega, F. Carraro, C. Martini, F. Bondavalli and M. Botta (2008). Structure-based optimization of pyrazolo[3,4-d]pyrimidines as Abl inhibitors and antiproliferative agents toward human leukemia cell lines. Journal of Medicinal Chemistry 51 (5), 1252-1259.

[61] Karai O., Y. Aouine, H. Faraj, A. Alami, M. R. Kabbour, A. El Hallaoui and M. Bouksaim (2018). Synthesis, characterization and antibacterial activity of Methyl (2R)-2-benzamido-2$\{[(1 \mathrm{R})-2$-methoxy-2-oxo-1-phenylethyl $]$ amino $\}$ acetate. Medicinal Journal of Chemistry 7 (4), 267-271.

[62] Daidone G., S. Plescia, B. Maggio, D. Schillaci, D. Raffa and M. V. Raimondi (2004). Synthesis and in vitro antileukemic activy of new 4-trizenopyrazole derivatives. IL Farmaco 59, 413-417.

[63] Schenone S., O. Bruno, A. Ranise, F. Bandavaui, C. Brullo, P. Fossa, L. Mosti, G. Menozzi, F. Carraro, A. Naldini, C. Bernini, F. Manetti and M. Botta (2004). New pyrazolo[3,4d]pyrimidines endowed with A431 antiproliferative activity and inhibitory properties of Src phosphorylation. Bioorganic Medicinal Chemistry Letter 14 (10), 2511-2517.

[64] Nosrat O. M., P. Jafar, S. Bahman and R. Mehdi (2013). Facile Regioselective Synthesis of Novel bis - Thiazole Derivatives and Their Antimicrobial Activity. Archiv der Pharmazie Chemistry in Life Science 346, 860-864. 
[65] Zhu G. D., J. Gong, V. B. Gandhi, K. Woods, Y. Luo, X. Liu, R. Guan, V. Kinghofer, E. F. Johnson, V. S. Stoll, M. Mamo, Q. Li, S. H. Rosenberg and V. L. Giranda (2007). Design and synthesis of pyridine-pyrazolopyridine-based inhibitors of protein kinase B/Akt. Bioorganic Medicinal Chemistry 15 (6), $2441-2452$.

[66] Huang S., R. Lin, Y. Yu, Y. Lu, P. J. Connolly, G. Chiu, S. Li, S. L. Emanuel and S. A. Middleton (2007). Synthesis of 3(1H-benzimidazol-2-yl)-5-isoquinolin-4-ylpyrazolo[1,2b]pyridine, a potent cyclin dependent kinase 1 (CDK1) inhibitor. Bioorganic Medicinal Chemistry Letter 17 (5), $1243-1245$.

[67] Warshakoon N. C., S. Wu, A. Boyer, R. Kawamoto, S. Renock, K. Xu, M. Pokross, A. G. Evdokimov, S. Zhou, C. Winter, R. Walter and M. Mekel (2006). Design and synthesis of a series of novel pyrazolopyridines as HIF-1alpha prolyl hydroxylase inhibitors. Bioorganic Medicinal Chemistry Lette, 16 (21), 5687-5690.

[68] Sherif M. H. and Amal M. Y. (2015). Synthesis and anticancer evaluation of some fused coumarino-[4,3-d]-pyrimidine derivatives. Research on Chemical Intermediate 41, 383-390.

[69] Elsherbiny H. E. S, Y. M. Amal and A. A. El. Sara (2018). Synthesis of New 2-N-Substituted Amino-5-aryl-1,3-thiazoles as Antitumor Agents. Latin American Journal of Pharmacy 37 (8), 1594-1601.

[70] Amal M. Y. Moustafa and B. Safyah (2019). Synthesis of Some Hybrid 7-Hydroxy Quinolinone Derivatives as Anti Breast Cancer Drugs. Research on Chemical Intermediate 45 (7), 3895-3912. 